\title{
Disease dynamics and potential mitigation among restored and wild staghorn coral, Acropora cervicornis
}

The threatened status (both ecologically and legally) of Caribbean staghorn coral, Acropora cervicornis, has prompted rapidly expanding efforts in culture and restocking, although tissue loss diseases continue to affect populations. In this study, disease surveillance and histopathological characterization were used to compare disease dynamics and conditions in both restored and extant wild populations. Disease had devastating effects on both wild and restored populations, but dynamics were highly variable and appeared to be site-specific with no significant differences in disease prevalence between wild versus restored sites. A subset of 20 haphazardly selected colonies at each site observed over a four-month period revealed widely varying disease incidence, although not between restored and wild sites, and a case fatality rate of $8 \%$. A tropical storm was the only discernable environmental trigger associated with a consistent spike in incidence across all sites. Lastly, two field mitigation techniques, (1) excision of apparently healthy branch tips from a diseased colony, and (2) placement of a band of epoxy fully enclosing the diseased margin, gave equivocal results with no significant benefit detected for either treatment compared to controls. Tissue condition of associated samples was fair to very poor; unsuccessful mitigation treatment samples had severe degeneration of mesenterial filament cnidoglandular bands. Polyp mucocytes in all samples were infected with suspect rickettsia-like organisms; however, no bacterial aggregates were found. No histological differences were found between disease lesions with gross signs fitting literature descriptions of white-band disease (WBD) and rapid tissue loss (RTL). Overall, our results do not support differing disease quality, quantity, dynamics, nor health management strategies between restored and wild colonies of $A$. cervicornis in the Florida Keys. 
2 Margaret W. Miller ${ }^{1 *}$, Kathryn E. Lohr ${ }^{2}$, Caitlin M. Cameron ${ }^{1,2}$, Dana E. Williams ${ }^{1,2}$, Esther C.

3 Peters $^{3}$

4 1. NMFS-Southeast Fisheries Science Center, 75 Virginia Beach Dr., Miami FL 33149, 5 margaret.w.miller@noaa.gov

6 2. Rosenstiel School of Marine and Atmospheric Sciences, University of Miami, USA

7 3. Department of Environmental Science \& Policy, George Mason University, USA

8 Keywords: Florida Keys, recovery, tropical storm, histopathology, incidence, restoration 


\section{INTRODUCTION}

10 Disease, in conjunction with co-occurring and likely interacting stressors such as storms

11 and warming temperatures, is the major driving factor placing the Caribbean staghorn coral,

12 Acropora cervicornis, at risk of extinction (reviewed in Aronson \& Precht 2001; IUCN 2012).

13 Understanding the diagnostics and etiology of diseases affecting A. cervicornis populations

14 remains problematic, and effective management strategies to combat this ongoing threat to

15 species survival remain elusive. Despite more than a decade of focused research effort, there

16 remains a dearth of strict diagnostic characterization for field cases of disease in A. cervicornis

17 and, perhaps consequently, inconsistency in naming suspected disease conditions in published

18 literature. Most authors simply apply the historical label of white-band disease (WBD) (Aronson

19 \& Precht 2001; Gignoux-Wolfsohn et al. 2012; Gladfelter et al. 1977; Peters 1984; Vollmer \&

20 Kline 2008), a condition that was first described in A. palmata from Tague Bay, St. Croix, US

21 Virgin Islands, as "a sharp line of advance where the distally located, brown zooxanthella-bearing

22 coral tissue is cleanly and completely removed from the skeleton, leaving a sharp white zone

23 about 1-cm wide that grades proximally into algal successional stages...." (illustrated in Fig 1A;

24 Gladfelter 1982). Peters et al. (1983) found the same disease signs present on A. cervicornis

25 colonies of the deeper forereef at Tague Bay (Table 1). A second type of WBD was recognized in

26 the 1990s, WBD-II, distinguished by a section of bleached tissue at the tissue margin (Table 1;

27 Fig 1F; Gil-Agudelo et al. 2006; Ritchie \& Smith 1998).

28 The lesions attributed to WBD-I on Caribbean acroporids have varied in their patterns

29 (smooth or ragged tissue margins) and rate (linear tissue loss less than $1 \mathrm{~mm} \mathrm{~d}^{-1}$ to more than 14

$30 \mathrm{~mm} \mathrm{~d}^{-1}$, Gladfelter 1982), and published descriptions have not always been clear (Rogers 2010).

31 For example, "rapidly advancing white band of diseased tissue" (Vollmer \& Kline 2008) is not

32 appropriate because it is a band of white denuded skeleton, not white tissue, that appears

33 progressively (does not itself advance) from the base or middle of a branch toward the branch tip 
34 as the necrotic tissue (confirmed by histological examination) peels off, sloughs, or lyses and

35 disappears from the skeleton (Gladfelter 1982; Peters et al. 1983). In addition, recent observation

36 of acute tissue loss in A. cervicornis in the Florida Keys indicates that lesions rarely present as a

37 uniform-in-width band of denuded skeleton, as in the original description for WBD (quote above,

38 Fig 1C). Rather, initial lesions often show irregular sloughing of tissue with rapid enlargement of

39 lesions anywhere on the surface of a branch, yielding multifocal swaths of bright white denuded

40 skeleton. Due to lack of consistency with the original description (quoted above), some authors

41 have refrained from using the name WBD-I in favor of the more general term rapid tissue loss

42 (RTL) (Table 1, Fig 1D, Williams \& Miller 2005). It should be noted that a similar but unnamed

43 condition was described much earlier by Bak and Criens (1981) and that there is no evidence

44 whether or not this condition is distinct from that referred to as WBD-I by other authors. Tissue

45 loss on a colony can also appear as a combination of lesion types (Fig 1E).

46 The ability to accurately identify disease in the field is further confounded by the

47 activities of corallivores, such as the snail Coralliophila abbreviata, the polychaete Hermodice

48 carunculata, and damselfishes or butterflyfishes, because they frequently remove $A$. cervicornis

49 tissue and leave feeding scars that may be difficult to distinguish from disease (Table 1; Bruckner

50 2001; Miller \& Williams 2006; Sutherland et al. 2004). In addition, Williams and Miller (2005)

51 found that C. abbreviata that were feeding at tissue-loss margins on disease-affected colonies

52 could apparently transmit this condition when subsequently allowed to feed on apparently healthy

53 branches, resulting in continued tissue loss; thus, predation may exacerbate disease spread

54 through a population.

55 Acropora cervicornis'status under the USA Endangered Species Act carries a legal

56 mandate to orchestrate its recovery (i.e., a sustainable status where ESA protections are no longer

57 needed to prevent extinction). This mandate, combined with a growing consensus that decline

58 has reached a point where natural resilience is likely compromised, has led to increasing efforts to 
59 culture and restock populations of $A$. cervicornis (reviewed in Young et al. 2012). This

60 unprecedented movement toward proactive intervention and population engineering in a coral

61 reef foundation species is occurring within a historical context of mixed success in previous case

62 studies in the fields of fisheries and wildlife management (Carlsson et al. 2008; Champagnon et

63 al. 2012; Hilborn \& Eggers 2000). The primary concern for such an endeavor is the potential for

64 unintended introductions of deleterious genetic or health consequences within the imperiled

65 population or its ecosystem (Baums 2008; Cunningham 1996). For this reason, the genetic status

66 of imperiled coral populations, including A. cervicornis, has received increasing attention in

67 recent years and strides have been made in addressing the potential genetic risks of culturing and

68 restoring $A$. cervicornis populations, such as outbreeding depression or genetic bottlenecks in

69 cultured stocks (Baums et al. 2010; Hemond \& Vollmer 2010).

70 Addressing potential health risks of transplanting Acropora cervicornis, on the other

71 hand, is much more challenging. While explicit risk assessment and risk management

72 frameworks have been proposed and applied in wildlife translocation projects, effective

73 application requires at least qualitative knowledge of pathogens, vectors, and susceptibilities

74 operating in the given species (e.g., Lenihan et al. 1999; Sainsbury \& Vaughan-Higgins 2012).

75 The limited use of multidisciplinary effective diagnostic tools and lack of robust etiological

76 characterization for coral disease in general, and in A. cervicornis in particular (Rogers 2010;

77 Sutherland et al. 2004), impairs efficient health risk management. Until a better knowledge base

78 is built for health management of coral populations, presumed risk-averse 'best practices' are

79 currently applied in nursery culture and outplanting (or restocking) of $A$. cervicornis. These

80 practices include emphasis on field-based (rather than land-based) culture, avoiding outplanting

81 colonies with visual signs of ill health (discoloration or tissue loss), geographic matching of

82 source populations, nursery sites, and target sites, and targeting outplants at sites where there is 
83 evidence of prior occupation, but without extant live wild colonies (Johnson et al. 2011; L Gregg,

84 Florida Wildlife Conservation Commission, pers. comm.).

85 The severe and ongoing impact of coral disease on coral populations begs the question of

86 potential mitigation actions that could be applied in the context of local management (Beeden et

87 al. 2012; Bruckner 2002; Raymundo et al. 2008). If effective, such targeted mitigation actions

88 would seem particularly relevant and useful as part of an integrated health-risk management

89 component in a population restocking program. Both nursery and field practitioners have

90 anecdotally reported simple interventions, such as separating apparently healthy tissues from

91 diseased colonies or applying a physical barrier (e.g., band of clay or epoxy) to the diseased

92 tissue margin to control tissue loss (Johnson et al. 2011; Raymundo et al. 2008), but no controlled

93 tests of such mitigation treatments have been published. Indeed, we are aware of only two

94 published studies reporting on successful field disease mitigation treatments; $80 \%$ successful

95 excision of distal Turbinaria spp. white-syndrome lesions (Dalton et al. 2010), and anecdotal

96 success of aspirating black-band microbial mats with subsequent clay seal over the tissue margin

97 (Hudson 2000). However, neither study examined the treated colonies' tissues microscopically to

98 determine why their treatments were successful.

99 The objectives of the present study were to: (1) characterize disease dynamics using

100 targeted disease surveillance in outplanted/transplanted versus wild populations of $A$. cervicornis

101 to provide a more robust scientific basis for judging the health risks associated with outplanting,

102 and (2) perform controlled tests of two simple mitigation treatments in situ to determine if they

103 significantly arrested tissue loss in affected colonies. For both objectives, and to improve our

104 understanding of the tissue loss diseases in this species, the histopathology of selected fragments

105 from unmanipulated and treated branches was evaluated using light microscopy. 
109 A. cervicornis populations in the upper Florida Keys National Marine Sanctuary. Restored

110 populations were outplanted between 2007 and 2011 as part of previous projects by the Coral

111 Restoration Foundation (CRF) or the National Marine Fisheries Service-Southeast Fisheries

112 Science Center. Each restored site hosted either outplanted (i.e., from field nursery culture) or

113 transplanted (i.e., from nearby wild populations) colonies, with one site (Aquarius) hosting a

114 mixture of both sources of restored colonies (Table 2). These restored sites were deliberately

115 established in areas devoid of native wild colonies and are in shallow (3-8 $\mathrm{m})$ fore-reef habitats,

116 including Key Largo Dry Rocks, French, Molasses, Pickles, and Conch Shallow reefs (Table 2;

117 Supplementary Fig S1). An additional restored site (Aquarius) was surveyed in 2011 only and

118 was located in the deeper fore-reef (14-16 m) of Conch Reef. Few wild A. cervicornis patches

119 are extant in the upper Florida Keys; three were identified for the current study to provide

120 comparison to the restored populations. These wild sites were all located in low-relief patch reefs

121 with partially consolidated rubble bottom at about 5-m depth and included an unnamed patch reef

122 off of Tavernier, FL (TavPatch sites A and B), and Little Conch reef. Periodic surveys were also

123 conducted at the CRF field nursery (origin of most restored colonies).

124 Temperature data was collected at surveyed reefs during the survey seasons with HOBO

125 pendant data loggers (UA-001-64; Onset Corporation). Loggers were not re-located at TavPatch

126 or Key Largo Dry Rocks after Tropical Storm Isaac so temperature data for those two sites is not

127 available in 2012.

128 The study was conducted under Florida Keys National Marine Sanctuary Permit \#

129 FKNMS-2011-032-A1.

\section{Surveillance}


131 Disease surveillance was conducted from May to November in 2011 and 2012 to target

132 the seasonal time-frame when acroporid disease was expected to be most active (Williams \&

133 Miller 2005; K. Nedimyer, pers. comm.). Surveys were conducted approximately every two

134 weeks in 2011 (total nine surveys) and monthly in 2012 (total seven surveys), each taking 2-3

135 days to complete. At each wild site, a fixed circular plot was marked with a center rebar stake

136 and used to delineate the study population for which prevalence was determined (i.e., percent of

137 colonies in the population that displayed signs of disease). Different plot sizes (8-m radius at Tav

138 Patch A and B, 10-m radius at Little Conch) were used at the wild sites to incorporate a minimum

139 of 25 colonies. At restored sites, the sample population consisted of the outplanted and/or

140 transplanted colonies present. The number of colonies tallied for individual site prevalence

141 estimates ranged from 23 to 163 according to the number of colonies available and the extent of

142 search during a given survey.

143 During each survey, every colony was recorded as either affected or unaffected with acute

144 tissue loss disease including both WBD and RTL descriptions (Table 1; i.e., bright white skeleton

145 with either a straight or jagged tissue margin on basal or interstitial portions of the colony or

146 multifocal). Corallivory was also common, so basal lesions with snails present or denuded

147 branch tips not passing a fork which are characteristic of fireworm feeding (Table 1; Fig 1G;

148 Shinn 1976) were not counted as disease. Prevalence was calculated for each site for every

149 survey and averaged for each site-by-year combination. A two-way, fixed-factor ANOVA, with

150 factors being site-type (restored versus wild) and year (2011 or 2012) and sites as replicates, was

151 conducted to determine if overall prevalence varied significantly between restored and wild sites

152 or years. In addition, as a qualitative comparison, disease prevalence observations were also

153 made during six surveys in 2011 and one in 2012 at the nearby field nursery (Coral Restoration

154 Foundation) from which all the outplanted colonies in the study had originated. 
156 tagged at each site in May 2012. At each survey, tagged colonies were photographed and a visual

157 estimate of percent of dead colony surface (in 5\% increments), attributed as either predation,

158 disease, or undefined, was recorded. After the fifth survey, disturbance from Tropical Storm

159 Isaac damaged or removed several tagged colonies at most sites, resulting in observations of

160 fewer than 20 colonies at the sixth survey. To determine disease incidence (rate of new disease

161 cases) over a survey interval, each colony observed with active disease that had been observed as

162 unaffected at the previous survey was counted as a new disease case. Incidence was expressed as

163 a proportion of observed tagged colonies displaying new cases of disease since the previous

164 survey and was standardized per week. Separate t-tests were used to determine if (1) incidence

165 averaged over time and (2) the proportion of tagged colonies that remained unaffected during

166 2012, differed between restored and wild sites.

167 We estimated partial mortality based on cumulative increase in rough visual estimates of

168 percent dead on each of the tagged colonies that was observed with disease. To help discern the

169 effect of Tropical Storm Isaac, we analyzed cumulative partial mortality for all cases that

170 occurred prior to the storm (through survey five), and then including new cases that were

171 observed at the survey following the storm (survey six). A z-test was used to compare the

172 proportion of affected wild vs. affected restored colonies showing severe cumulative partial

173 mortality (defined as greater than $80 \%$ ). We also tallied the case fatality rate as the percent of

174 cases (i.e., colonies that displayed disease signs during the course of the observation period)

175 undergoing complete mortality.

\section{Mitigation Experiment}

177 Two disease mitigation treatments were implemented to test effectiveness in arresting

178 tissue loss (Fig 2). The first treatment used a band of two-part marine epoxy (All-Fix Epoxy) 
179 applied around the branch to cover the disease margin of an affected colony, presumably

180 functioning as a physical barrier over the tissue-loss margin. The second treatment involved a

181 complete excision of live, apparently healthy, tips of branches distal to a disease margin using

182 handheld wire cutters. The excised fragment was then reattached to the reef substrate with epoxy

183 at a distance greater than $1 \mathrm{~m}$ from the parent colony. These treatments are referred to as epoxy

184 band (EB) and excision (EX) (Fig 2B-C), respectively. Lastly, a control treatment consisted of a

185 cable tie placed at or near a tissue loss margin on the same colony as a reference point to detect

186 continued tissue loss (Fig 1C or 1D). To prevent potential contamination, nitrile gloves were

187 used when manipulating colonies and were changed when moving between affected colonies. All

188 equipment that came into contact with diseased colonies was rinsed in a $10 \%$ bleach solution

189 following each dive.

190 The design and setup for this experiment, including sample size, timing, and placement of

191 replicates, were constrained by the availability of affected colonies with apparently active

192 disease. Due to permitting constraints in 2011, no experimental mitigation treatments were

193 performed on wild A. cervicornis colonies. In 2012, this stricture was lifted and treatments were

194 conducted on both restored and wild colonies. Distribution of experimental replicates among

195 sites and years is given in Table 2. Effort was taken to block treatments within the same colony if

196 it contained three or four (to include a histology sample) affected branches. However, this was

197 often not possible and so treatments were allocated sequentially to affected colonies as they were

198 encountered.

199 Rates of tissue loss in the observed diseased conditions were rapid so all experimental

200 replicates were scored as either (1) continued or (2) arrested tissue loss at an interval of

201 approximately one month after the treatment was implemented, and each treated colony was

202 photographed to document tissue loss progression. In some cases, corallivores were subsequently

203 observed on a treated or control colony. These replicates were excluded from analysis because 
204 continued tissue loss could not be confidently attributed to disease and hence would not

205 confidently constitute 'failure' of the treatment. Proportion of replicates with continued versus no

206 tissue loss after applying the treatment was compared among the three treatments using Chi-

207 Squared tests (for each year separately and for the years pooled).

\section{Histopathology}

209 To better characterize the observed disease conditions, tissue samples were collected in

2102011 from a subset of apparently healthy colonies $(n=21$, including at least one and up to four

211 colonies from each site, collected in June or late September 2011), diseased colonies observed in

212 the vicinity of the surveys $(n=12)$, and diseased samples collected from the colonies in the

213 mitigation experiment $(n=11)$ collected throughout the sampling season. In addition, two diseased

214 samples were collected from wild site Little Conch in 2012 to compare with the apparently

215 healthy samples collected at that site in 2011 . Samples were removed by cutting a 5-10 cm

216 portion of a branch including tissue and skeleton, using handheld wire cutters and placed in a

217 labeled 50-ml plastic centrifuge tube. After surfacing, the sample was immediately immersed in a

218 formaldehyde-based fixative solution (Z-Fix Concentrate, Anatech, Ltd., 1:4 dilution in

219 seawater). Sample tubes were capped, kept at ambient temperature in the shade, and shipped to

220 the Histology Laboratory at George Mason University for processing.

221 Each sample was photographed and the images compiled into trim sheets. Samples were

222 trimmed into approximately $2-\mathrm{cm}$ long fragments using a Dremel tool and diamond-coated tile-

223 cutting blade. The location of each cut was marked on the sample image on the trim sheet and

224 subsample numbers were assigned and marked on the trim sheet. Subsamples having a tissue loss

225 margin were enrobed in $1.5 \%$ agarose to trap material that might be present on the denuded

226 skeletal surface or in corallite or gastrovascular canal crevices. Subsamples were decalcified

227 using 10\% disodium ethylenediaminetetraacetic acid (EDTA) at pH 7, changing the solution 
228 every 24 to 48 hours. When completely decalcified, the subsamples were rinsed in running tap

229 water for about 30 minutes, trimmed into 2-3 mm slices and placed in cassettes, processed

230 through ethanols, cleared, and infiltrated with molten Paraplast Plus ${ }^{\circledR}$, then embedded in

231 Paraplast Xtra ${ }^{\circledR}$ (Peters et al. 2005). Sections (5- $\mu$ m thickness) were mounted on microscope

232 slides, stained with Harris's hematoxylin and eosin and Giemsa (Noguchi 1926) procedures, and

233 coverslipped with Permount ${ }^{\mathrm{TM}}$ mounting medium.

234 The sections were examined with an Olympus BX43 compound microscope and

235 photomicrographs obtained with an Olympus DP-72 camera. Semi-quantitative data (Jagoe 1996)

236 were collected from each subsample based on relative condition (tissue architecture, cellular

237 integrity, zooxanthellae abundance, pathological changes $)$ at the time of fixation $(0=$ Excellent,

238 1=Very Good, 2=Good, 3=Fair, 4=Poor, 5=Very Poor) and severity or intensity of tissue changes

239 from normal $(0=$ Within Normal Limits, $1=$ Minimal, $2=$ Mild, 3=Moderate, 4=Marked, 5=Severe $)$

240 (see Table S 1). Histoslides of A. cervicornis and A. palmata collected from the 1970s in the

241 Florida Keys (the earliest tissue samples located, before tissue loss was reported from this region)

242 were used to develop the "within normal limits" criteria for general coral tissue condition and

243 zooxanthellae condition/abundance scores, six specific cell or tissue parameters of polyp health,

244 bacterial aggregates (Peters et al. 1983), and suspect rickettsia-like organisms (RLOs) (Casas et

245 al. 2004; CS Friedman, pers. comm.). Presence/absence was noted for hypertrophied

246 calicodermis foci, necrotic cell spherules, apicomplexans (Upton \& Peters 1986), and suspect

247 ciliate predators. The developmental stage of gonads was noted, if present (Szmant 1986). Mean

248 scores for each sample were obtained (one or multiple sections were made, especially if enrobed

249 samples had been trimmed into four $\sim 2-3 \mathrm{~mm}$ slices for embedding; some sections did not

250 contain enough tissue for scoring) and checked for quality. Suspect RLO abundances were

251 visibly higher in Giemsa-stained sections since it demonstrates Rickettsia well (Noguchi 1926);

252 thus, estimates based on those sections were preferentially used. Descriptive statistics were 
253 calculated for the scored parameters in each group of samples (apparently healthy, disease

254 characterization, and mitigation treatments). Frequency distributions of the scores were

255 examined. Comparisons were made for the scored parameters between all apparently healthy and

256 diseased samples, successful and unsuccessful mitigation treatments, and WBD- and RTL-

257 affected samples using Student's t-tests and Mann-Whitney U-tests.

\section{RESULTS}

\section{Disease Dynamics}

Intermittent observations within the field nursery throughout 2011 yielded consistently

261 low prevalence of $0-1.7 \%$. However, disease prevalence in reef populations was highly variable

262 and largely site-specific with no consistent patterns between restored versus wild sites (Fig 3 A-

263 D). In 2011, wild sites showed relatively low prevalence with means of 1.5 to $4.4 \%$ during the

264 survey period and a peak of approximately $13 \%$ at TavPatch B in late June (Fig 3A). Meanwhile,

265 four of six restored sites showed generally high disease prevalence (i.e., survey period means of

$2669-17 \%$ and max of $26-41 \%$; Fig 3C) particularly from July through early October, while the

267 remaining two restored sites showed consistently low prevalence throughout 2011 (i.e., Key

268 Largo Dry Rocks and Conch Shallow had 2011 survey period means of 0.7 and 3.5\% prevalence

269 with one peak of $13 \%$, lower or similar to the wild sites; Fig. 3C). In contrast, during 2012, Key

270 Largo Dry Rocks and Conch Shallow showed among the highest prevalence patterns with survey

271 period means of $20 \%$ and peaks of $60-70 \%$ (Fig 3C). Little Conch (wild) consistently had the

272 highest site prevalence throughout the 2012 survey period (20-57\% range, mean 35\%; Fig 3B).

273 The temperature records indicate little temperature variation among sites during both

274 years (Fig 3E-F), suggesting that site-specific disease increases or outbreaks were not triggered

275 by temperature. Additionally, the accumulated thermal stress (i.e., the cumulative duration of 
276 temperature exposure $>30^{\circ} \mathrm{C}$ ) was greater in 2011 than in 2012 (Fig 3E-F), but this did not

277 correspond to higher disease prevalence. The mean prevalence during the survey period was

278 higher in all three wild sites and four of six restored sites in 2012 than 2011 . In contrast, the

279 passage of Tropical Storm Isaac (26 Aug 2012) did correspond to a ubiquitous spike in disease

280 prevalence across all sites (restored and wild). A two-way ANOVA using site means for each year

281 showed a significant effect of year $(p=0.032)$ but not of site-type $(p=0.786)$ nor the interaction

$282(\mathrm{p}=0.237)$. However, if the post-storm prevalence surveys are excluded in 2012, no factors are

283 significant, suggesting that higher overall disease prevalence in 2012 was attributable to the acute

284 effect of the storm.

285 Temporal patterns of disease incidence in 2012 are shown in Table 3 and further

286 emphasize the site-specific nature of disease dynamics in this population. Individual sites show

287 widely varying patterns of incidence, from persistent low incidence followed by a spike in the

288 fifth interval, following Tropical Storm Isaac (e.g., Pickles, TavPatch-A, TavPatch-B), to a

289 moderate level in the first three intervals followed by declining incidence (Molasses), to sites

290 with persistently high incidence from interval two (French, Little Conch), to sites with both an

291 early and a late peak (intervals two and six; Key Largo Dry Rocks)(Table 3). Average incidence

292 did not differ significantly between Restored and Wild sites ( 2 sample $\mathrm{t}$-test; $\mathrm{t}=0.323,6$ degrees

293 of freedom, $\mathrm{P}=0.757)$ though this test has very low power $(0.05)$.

294 Among the initial tagged population of 160 colonies in 2012, a total of 89 disease cases

295 were identified with a case fatality rate of $7.9 \%$. The proportion of colonies that remained

296 unaffected throughout the study (non-cases, Table 3) was not significantly different between

297 restored and wild sites ( $\mathrm{t}$-test, $\mathrm{p}=0.686$ ). Prior to the storm (up to survey 5), only $\mathrm{n}=53$ cases

298 occurred. Fifty-two \% of these cases showed no detectable increment of partial mortality (Fig. 4)

299 and there were similar frequencies of cumulative partial mortality between restored and wild

300 cases. When the storm interval is included, disease-affected restored colonies had a significantly 
301 greater likelihood of showing severe (>80\%) partial mortality than affected wild colonies (Fig. 4;

302 z-test $\mathrm{p}=0.005)$.

\section{Mitigation Experiment}

304

Approximately $60-70 \%$ of control replicates in each year showed continued tissue loss

305 after one month (Fig. 5). In other words, around one-third of the replicates we thought to be in an

306 active diseased state based on gross visual signs were, in fact, dormant during the following one-

307 month period of observation. The proportion of experimental replicates displaying tissue loss

308 about one month after the treatment application did not differ significantly among EB, EX, and

309 Control treatments for either year analyzed separately $\left(2011: \chi^{2}=0.134, \mathrm{p}=0.935 ; 2012: \chi^{2}=1.502\right.$, $310 \mathrm{p}=0.472)$ nor for both years pooled $\left(\chi^{2}=0.953, \mathrm{p}=0.621\right)$. However, the power of these tests is 311 very low (0.059-0.173) so negative results should be treated with caution.

\section{Histopathological Observations}

313 Summary statistics for the apparently healthy samples collected during the surveys,

314 diseased samples for characterization, and diseased mitigation samples are presented in Table 4.

315 The apparently healthy samples were in very good to fair condition, had more zooxanthellae in

316 gastrodermal cells, numerous mucocytes filled with pale, frothy mucus that were about the same

317 height as the ciliated columnar cells of the epidermis (Fig 6A), and intact cnidoglandular bands of

318 the mesenterial filaments (Fig. 6B). A third of the samples had minimal gaps (complete loss of

319 tissue) in the calicodermis, mesoglea, and epidermis of the surface body wall covering costal

320 ridges on the outside of the polyp's theca. The calicodermis toward branch surfaces was

321 squamous to columnar, relatively thick, and contiguous over the mesoglea; calicoblasts often

322 showed plasmallema extensions on their apical surfaces (toward the skeleton) and pale pink to

323 clear cytoplasm (Fig. 6C). Deeper calicodermis was squamous and the cytoplasm contained fine 
324 eosinophilic granules. None of the samples contained bacterial aggregates, but almost all had

325 mild to marked numbers of suspect RLOs, identified as basophilic clusters of large pleomorphic

326 to uniformly coccoid cells staining red to purple with Giemsa, in mucocytes on polyp oral discs

327 and tentacles (Fig. 6D) and in cnidoglandular bands of the mesenterial filaments (Fig. 6E).

328 Coccidian oocysts were seen in two samples. Early oocytes were found in two samples, but no 329 spermaries were observed.

330 Generally, characteristics of the diseased tissue samples collected from restored colonies

331 at a range of sites throughout the 2011 season included moderate to severe attenuation of the

332 epithelia and mesoglea, numerous hypertrophied mucocytes or reduced number of mucocytes in

333 the epidermis (Fig 6F), and reduced numbers of zooxanthellae (but not entirely missing).Cells of

334 the cnidoglandular bands showed varying degrees of atrophy, loss, necrosis or apoptosis, and

335 dissociation (Fig. 6G). Moderate to severe costal tissue loss was noted, beginning in the apical

336 polyp and increasing toward the tissue loss margin. The calicodermis varied in thickness and

337 condition, but deeper and closer to the tissue loss margin was thinner, had fewer cells, and

338 calicoblasts lysed or sloughed off the mesoglea (Fig 6H); sometimes foci of hypertrophied

339 columnar calicoblasts with apical fine acidophilic granules were present at lysing tissue margins.

340 None of these samples had bacterial aggregates, but all had suspect RLOs in mucocytes of the

341 oral disc, tentacle epidermis, and cnidoglandular bands, and infected mucocytes were also present

342 in gastrodermis lining the gastrovascular canals and mesenteries (Fig. 6I-J). Suspect RLO cells

343 filling epidermal mucocytes were usually large $(1-2 \mu \mathrm{m})$ and pleomorphic (Fig. 6H), whereas

344 those in gastrodermal mucocytes were usually smaller $(0.2-1 \mu \mathrm{m})$ and coccoid (Fig. 6I) and those

345 in cnidoglandular band mucocytes could be either morphology or size within a particular cell.

346 Tissue loss margins displayed lysing coral cells with vacuolation and necrosis or

347 apoptosis of cells remaining on the skeleton and sloughing of epithelial cells from mesoglea.

348 Some agarose-enrobed samples had free-swimming ciliates containing zooxanthellae on the 
349 denuded skeleton in $24 \%$ of samples, but were very rarely in contact with coral tissue or within

350 the lumens of gastrovascular cavities or canals even near the tissue loss margin; ciliates without

351 zooxanthellae were present in fewer numbers on $10 \%$ of samples, but farther away from tissue

352 remnants. In addition, circumscribed masses of necrotic cell debris and zooxanthellae, in various

353 states of further degradation and lysing, were present in $33 \%$ of the diseased samples. About $1-2$

$354 \mathrm{~mm}$ in diameter, they appeared to form as calicoblasts surrounding gastrovascular canals released

355 from the skeleton and mesoglea surrounded gastrodermal cells or mesenterial filaments or

356 epidermis fragments, trapping the degenerating epithelial cells within, but eventually lysing and

357 breaking apart. All of the diseased samples obtained from colonies used in the mitigation

358 treatments had similar pathological changes (Table 4). Early to mid-stage developing oocytes

359 were found in $10 \%$ and $5 \%$ of the samples, respectively, but no spermaries were observed.

360 Evaluation of the frequency distributions of the data to determine normality revealed that

361 most parameters had a bimodal distribution, divided between the apparently healthy and diseased

362 tissues (Table S 2), so the distributions were further examined within these categories. For

363 example, Epidermal Mucocytes Condition had no overlap in scores, with apparently healthy

364 samples showing mostly mild changes and diseased mostly severe changes. Parameters with

365 minimal overlap included General Condition 100x, Zooxanthellae Condition 100x, Dissociation

366 of Mesenterial Filaments, Costal Tissue Loss, and Calicodermis Condition. Parameters with

367 broader frequency distributions of similar scores for both diseased and apparently healthy

368 samples included Mesenterial Filament Mucocytes, Degeneration Cnidoglandular Bands, and

369 Epidermal and Filament RLOs.

370 Comparison of the apparently healthy samples with all diseased samples (Fig. 7A)

371 revealed that all parameter scores were significantly different, except for Epidermal and Filament

372 RLOs ( $p=0.165$ and 0.767, respectively, t-test, Table S 3). Epidermal RLOs were judged to be

373 moderate to marked in severity; filament RLOs were mostly judged to be minimal to marked in 
374 severity in both groups. For the samples in the mitigation experiment (Fig. 7B), histological

375 parameters were significantly different between successful and unsuccessful treatments only for

376 Mesenterial Filament Mucocytes and Degeneration of Cnidoglandular Bands $(\mathrm{p}=0.0097$ and

377 0.017, respectively, Mann-Whitney U-test, Table S 3). Number of mucocytes in the filaments was

378 markedly fewer in samples from colonies where mitigation was not successful, in addition the

379 filament epithelium had moderate to severe atrophy, loss of cnidocytes and acidophilic granular

380 gland cells, and necrosis or apoptosis of remaining cells. Samples categorized as WBD or RTL in

381 their patterns of tissue loss (Fig. 7C) only differed in Epidermal RLOs scores ( $p=0.031$, Mann-

382 Whitney U-test, Table S 3).

\section{DISCUSSION}

Surveillance of multiple wild and restored populations of staghorn coral in the Florida

385 Keys during two years emphasize the severe, ongoing disturbance that disease invokes in this

386 endangered species. Devastating disease outbreaks appear intermittently in both wild and

387 restored patches that have appeared healthy for a number of years. For example, colonies at all

388 three wild sites and restored colonies at Key Largo Dry Rocks appeared healthy with minimal

389 partial mortality that was mostly attributable to fireworm predation throughout the 2011

390 surveillance. However, two of these four sites (one wild, one restored) were devastated by

391 disease in 2012. All apparently healthy and diseased samples collected in both years were

392 infected with a microorganism that we believe to be, based on morphology and staining with

393 Giemsa, the Rickettsiales-like bacterium found by (Casas et al. 2004) using molecular techniques

394 (Table 4, Fig. 7A). Although Casas et al. (2004) dismissed this microorganism as a potential

395 pathogen of staghorn corals because it was present in apparently healthy and diseased samples, as

396 well as other coral species, our histopathological examinations revealed that this microorganism 
397 is infecting polyp mucocytes. While a ubiquitous infection in the absence of gross disease signs

398 might be interpreted as commensalism or mutualism rather than parasitism, it could also mean

399 that the infection is still in an early stage or that the coral has been able to maintain its tissues.

400 The intensity of the infection in mucocytes also raises a third possibility that this infection may

401 be altering the coral's mucous secretions and hence, increasing the susceptibility of the coral to

402 other environmental stressors and tissue loss. This third scenario would suggest a ubiquitous

403 compromised health condition affecting the population. There is no evidence that disease

404 dynamics nor histological characterization are different between wild and restored colonies

405 within the study population, which indicates that different disease risk management would not be

406 warranted.

407 The high rates of disease prevalence documented in the current study (Fig 3) are not

408 unprecedented as overall average disease prevalences of more than $25 \%$ have been reported for

409 individual site surveys in Panama, Belize, Cayman Islands, St. Thomas USVI, Antigua, and

410 Curaçao for A. cervicornis (Fogarty 2012; Vollmer \& Kline 2008) and for Acropora spp. (Ruiz-

411 Moreno et al. 2012). However, the peak disease prevalence observed in the current study (

$41270 \%$ ) is substantially higher than reported in these other Caribbean studies. Somewhat lower, but

413 still substantial, average levels of Acropora spp. disease prevalence (8-12\%) are reported in

414 multi-year, Caribbean-wide, general coral condition surveys (Marks \& Lang 2007; Ruiz-Moreno

415 et al. 2012). In comparison, disease prevalence in Pacific acroporid corals are reported in the

416 range of 9-13\% (three sites in the Great Barrier Reef, Willis et al. 2004), or 2-10\% (one site in

417 the Northwest Hawaiian Islands, one site in American Samoa; Aeby et al. 2011) while more

418 extensive surveys in three years across the entire Indo-Pacific region indicate an acroporid

419 disease prevalence of around 4\% (Ruiz-Moreno et al. 2012).

420 The existence of disease-resistant genets within A. cervicornis has been reported at a

421 frequency of $6 \%$ in a studied population of 49 genets in Panama (Vollmer and Kline 2008). Four 
422 of the restored populations surveyed in this study are in fact genotypically depauperate,

423 containing the same three genets, while the other two restored populations were genotypically

424 more diverse (Table 2). Colonies at the three wild sites have not been genotyped, but multiple

425 genets and high genetic diversity have been previously documented in wild populations of $A$.

426 cervicornis in the Florida Keys (Baums et al. 2010; Hemond and Vollmer 2010). Thus, it is likely

427 that multiple genets were present in each of these sites as well. The detection of potentially

428 disease-resistant genets seems problematic in these populations. Among the three wild sites, we

429 might have surmised possible disease-resistant genets within these presumably genotypically-

430 diverse patches given low disease prevalence in 2011. However, all of the tagged colonies at

431 wild site Little Conch were observed with disease at some point during 2012 (Table 3). An

432 important goal of Caribbean Acropora population enhancement strategies is the nursery culture of

433 stress-resistant genotypes or phenotypes in order to propagate hardier restored populations (e.g.,

434 Bowden-Kerby \& Carne 2012). The current results showing (1) extreme variation in disease

435 manifestation over sites and years, and (2) generally lower manifestation of disease within the

436 nursery environment than in nearby reef outplanted populations (despite similar suspect RLO

437 infection levels), reveal a challenge in accurately identifying these hardier candidates while

438 emphasizing that the environmental factors limiting survivorship of A.cervicornis persist in the

439 'wild' reef habitat of this region.

440 Similarly, the site-specific nature of both disease prevalence and incidence patterns (i.e.,

441 patchy but not spatially autocorrelated) challenges the hope of identifying specific environmental

442 triggers for disease, at least on the site scale. While no severe warm thermal anomalies occurred

443 during the duration of this study, accumulated thermal stress (e.g., duration of exposure $>30^{\circ} \mathrm{C}$ )

444 was greater in 2011 than 2012 (Fig. 3E, F) — corresponding to mild bleaching observed in some

445 wild colonies during September-October 2011 (none in 2012) - but not greater disease impacts.

446 Previous and repeated reports of A. cervicornis disease in the Florida Keys have occurred in late 
447 spring to mid-summer (April-July; Williams and Miller 2005; K. Nedimyer pers. comm.; M.

448 Miller, pers. obs.), not coinciding with the seasonal temperature peaks which occur in

449 September-October. The only coherent spike in disease prevalence and incidence that was

450 discernible across all sites corresponded to the passage of Tropical Storm Isaac (Fig. 3),

451 corroborating the hypothesis that storm disturbance may be an important coral disease trigger

452 (Brandt et al. 2013; Bruckner \& Bruckner 1997; Knowlton et al. 1981; Miller \& Williams 2006).

453 The only significant difference we were able to discern between restored and wild

454 colonies was in the degree of partial mortality during the storm interval, with restored colonies

455 having greater partial mortality than wild colonies (Fig. 4). One limitation of the current study is

456 in the spatial confounding of the restored and wild sites, with the former restricted to more

457 exposed, mostly shallow fore-reef habitats and the latter in somewhat more sheltered patch reef

458 habitats. It is likely that this habitat difference accounts for the apparent greater vulnerability of

459 restored colonies to storm-associated disease mortality rather than any inherent characteristic of

460 the colonies.

461 Our mitigation tests did not detect any significant benefit, in terms of preventing tissue

462 loss over a four-week period, from either excision or epoxy-band treatment. However, high

463 variability in response of both treatments, as well as the controls, yielded low power in the

464 statistical tests and several other observations may affect the interpretation of the somewhat

465 inconclusive results. First, there was no hint of harm accruing to either treatment (Fig 5).

466 Secondly, during circumstances of high disease prevalence we commonly observed, a

467 'successful' excision (as observed one month after treatment) or another area on a successfully

468 epoxy-banded colony to resume tissue loss at a later time. This suggests re-activation of disease

469 (or reinfection with a pathogenic microorganism) can occur in a given colony in environments

470 with high disease 'load'. On the other hand, if treatment replicates that were implemented at

471 times and sites with high prevalence (arbitrarily set at $>15 \%$ ) are excluded, the remaining 
472 replicates indicate significantly lower frequency of tissue loss for treatments (especially

473 excisions) vs. controls $\left(\mathrm{X}^{2}\right.$ test; $\mathrm{p}=0.014$; see Table $\left.\mathrm{S} 4\right)$. Our results and observations suggest

474 that if mitigation interventions are attempted, branch-tip excisions are perhaps more likely than

475 epoxy bands to be successful. Histologically, tip tissue may be in better condition than that at the

476 tissue-loss margin and resources are directed toward the tips rather than bases in this species

477 (Highsmith 1982). Also, mitigation appears to be more successful in isolated cases rather than in

478 areas with more disease. Unfortunately, conditions with low disease prevalence (arbitrarily

479 examined as $<15 \%$ ) occurred in only 31 of our 56 individual site surveys in 2012 .

480 The histopathological examinations revealed several other explanations for variation in

481 mitigation treatment success, despite the challenges in assigning a semi-quantitative score to

482 observations constituting a continuum. The only significant differences in scores between the

483 successful versus the unsuccessfully treated branches were the greater loss of mesenterial

484 filament mucocytes and degeneration of the cnidoglandular bands of the filaments in samples

485 from colonies that had unsuccessful treatments. The filament epithelium lines the free edges of

486 mesenteries in the gastrovascular cavity below the actinopharynx in the polyp; the specialized

487 acidophilic granular gland cells of this epithelium release enzymes to break down food particles.

488 The number and size of gland cells and mucocytes in the cnidoglandular band increase, whereas

489 ciliated cells decrease, aborally in normal A.cervicornis tissue. Cell loss, necrosis, and lysing in

490 the cnidoglandular bands indicate that the polyp is no longer able to process particulate food in

491 the gastrovascular cavity. In addition, although condition of the zooxanthellae, which also supply

492 nutrients to the coral, appears to remain unaffected until the host tissue is sloughing off the

493 skeleton, their numbers are reduced as the host condition deteriorates. However, due to our

494 inability to visually detect changes in coral pigmentation until zooxanthellae numbers are reduced

495 by more than 50 percent (e.g., Jones 1997), the tissue grossly appears to be intact and "normal,"

496 when it may not be so microscopically. The ubiquitous presence of the suspect RLO infections 
497 and their apparent association with mucocyte stress and loss raises the possibility that most, if not

498 all, the A.cervicornis population's health is compromised. Thus, without microscopic

499 examination, it is difficult, if not impossible, to identify the "best candidates" for mitigation

500 treatment.

501 Exactly what the impact of the suspect RLOs is on the A. cervicornis colonies is

502 conjecture at this point, but based on the behavior of similar obligate intracellular bacteria, their

503 replication within host cells requires substantial energy (Fryer \& Lannan 1994) resulting in tissue

504 atrophy and necrosis (Friedman et al. 2000; Sun \& Wu 2004). Nutritional stress may be a primary

505 reason why the zooxanthellae are gradually lost and calicoblasts lyse (Schoepf et al. 2013; Weis

506 2008). The coral cannot maintain its tissues with the loss of these host and algal cells that are

507 crucial to its survival. Infected mucocytes eventually die and are released from the epithelium, as

508 seen in this study, and the coral may not be able to replace them if nutritional resources are

509 compromised. Reduction in mucocytes means the loss of the coral's protection against

510 sedimentation and microorganisms, as well as heterotrophic feeding (Brown \& Bythell 2005;

511 Ritchie 2006). Investigation of the pathogenesis of the suspect RLO infection is continuing,

512 noting that other bacteria (Vibrio harveyi, Serratia marcescens, unspecified) have been implicated

513 in the acute loss of tissue from Caribbean acroporids (Gil-Agudelo et al. 2006; Kline \& Vollmer

514 2011; Patterson et al. 2002). Transcriptome analysis shows gene expression alterations in

515 immunity, apoptosis, cell growth, and remodeling in WBD (Libro et al. 2013); and multiple

516 pathogens may be involved or be different in specific cases requiring histopathological

517 examinations (Work \& Aeby 2011). However, ciliates do not seem to be a major factor in tissue

518 loss in our study. Bacterial aggregates first proposed to be the pathogen (Peters et al. 1983) were

519 not present in any of these samples. Work \& Aeby (2014) observed diverse cell-associated

520 microbial aggregates (CAMA) in Indo-Pacific corals and concluded that they were benign or

521 beneficial to the hosts; however, this may be premature, since long-term studies have not been 
522 undertaken in most of the coral species. Anderson et al. (2003) reported that the formation of

523 intracellular biofilm-like "pods" of Escherichia coli within the epithelium lining the urinary

524 bladders of mice had a role in chronic bladder infections. Histologically, no differences could be

525 discerned between WBD- and RTL-affected colonies, suggesting that differences in the patterns

526 of tissue loss (Table 1) are due to the intensity and duration of suspect RLO infections or the

527 identity of other biotic or abiotic stressors that trigger the loss. Thus, field identification of

528 diseased A. cervicornis lesions should be limited to acute or subacute tissue loss and the patterns

529 of distribution (e.g., focal, multifocal, diffuse). Samples collected from the same colonies in this

530 study are also being processed for molecular characterization of the microbial communities

531 associated with them at the diseased margin and in apparently healthy tissue from diseased or

532 unaffected colonies, as well as performing transmission electron microscopy, to help explain the

533 pathogenesis of tissue loss.

534 Overall, our results confirm the devastating toll that disease continues to have on both

535 wild and restored populations of Caribbean staghorn coral and suggests that wild and restored

536 populations display similar disease conditions, dynamics, and impacts. These results emphasize

537 the continuing need to understand and effectively address disease impacts in this species, as well

538 as discover methods and run experiments to try and determine a way to minimize tissue loss of

539 diseased colonies. Unfortunately, the straightforward mitigation treatments tested in this study

540 provided ambiguous results. Given these results, population restoration might be viewed as a

541 necessary but stop-gap recovery measure, particularly in light of the suspect RLO infections of

542 mucocytes in nursery and wild colonies. Additional assessments of factors affecting the staghorn

543 corals and their tissue loss diseases are needed, including pathogen interactions between the

544 stocks (Friedman \& Finley 2003) and host genotype susceptibility (Vollmer \& Kline 2008). 
545 Acknowledgements. This study was made possible by support from UNCW/Aquarius Reef Base

546 program. The work would not have been possible without the invaluable collaboration and

547 support of K. Nedimyer (Coral Restoration Foundation) for which we are truly honored and

548 grateful. Additional assistance in the field from O. Rutten, T. Roberts, A. Bright, and C. Kiel is

549 greatly appreciated. Songhee Kang, Patrick Pansoy, and William Norfolk provided support in the

550 George Mason University Histology Laboratory. 
551

552

553

554

555

556

557

558

559

560

561

562

563

564

565

566

567

568

569

570

571

572

573

574

575

576

577

578

579

580

581

582

583

584

585

586

587

588

589

590

591

592

593

594

595

596

597

598

599

\section{LITERATURE CITED}

Aeby GS, Bourne DG, Wilson B, and Work TM. 2011. Coral diversity and the severity of disease outbreaks: A cross-regional comparison of Acropora White Syndrome in a species-rich region (American Samoa) with a species-poor region (Northwestern Hawaiian Islands). Journal of Marine Biology 2011:ArticleID 490198.

Anderson GG, Palermo JJ, Schilling JD, Roth R, Heuser J, and Hultgren SJ. 2003. Intracellular bacterial biofilm-like pods in urinary tract infections. Science 301:105-107.

Aronson RB, and Precht WF. 2001. White-band disease and the changing face of Caribbean coral reefs. Hydrobiologia 460:25-38.

Bak RPM, and Criens SR. 1981. Survival after fragmentation of colonies of Madracis mirabilis , Acropora palmata and A. cervicornis (Scleractinia) and the subsequent impact of a coral disease. Proceedings of the 4th International Coral Reef Symposium 2:221-227.

Baums I, Johnson M, Devlin-Durante M, and Miller M. 2010. Host population genetic structure and zooxanthellae diversity of two reef-building coral species along the Florida Reef Tract and wider Caribbean. Coral Reefs 29:835-842.

Baums IB. 2008. A restoration genetics guide for coral reef conservation. Molecular Ecology 17:2796-2811.

Beeden R, Maynard J, Marshall P, Heron S, and Willis B. 2012. A framework for responding to coral disease outbreaks that facilitates adaptive management. Environmental Management 49:1-13.

Bowden-Kerby A, and Carne L. 2012. Thermal tolerance as a factor in Caribbean Acropora restoration. Proceedings 12th International Coral Reef Symposium 20A:(Abstract).

Brandt ME, Smith TB, Correa AMS, and Vega-Thurber R. 2013. Disturbance induced coral fragmentation as a driver of a coral disease outbreak. PLoS ONE 8:e57164.

Brown BE, and Bythell JC. 2005. Perspectives on mucus secretion in reef corals. Marine Ecology Progress Series 296:291-309.

Bruckner AW. 2001. Coral health and mortality. Recognizing the signs of coral diseases and predators. In: Humann P, and Deloach N, eds. Reef Coral Identification: Florida Caribbean Bahamas Including Marine Plants, 2nd edition, 240-271.

Bruckner AW. 2002. Priorities for effective management of coral diseases. NOAA Technical Memorandum NMFS-OPR-22. Silver Spring, MD.

Bruckner AW, and Bruckner RJ. 1997. Outbreak of coral disease in Puerto Rico. Coral Reefs 16:260-260.

Carlsson J, Carnegie RB, Cordes JF, Hare MP, Leggett AT, and Reece KS. 2008. Evaluating recruitment contribution of a selectively bred aquaculture line of the oyster, Crassostrea virginica used in restoration efforts. Journal of Shellfish Research 27:1117-1124.

Casas V, Kline DI, Wegley L, Yu YN, Breitbart M, and Rohwer F. 2004. Widespread association of a Rickettsiales-like bacterium with reef-building corals. Environmental Microbiology 6:1137-1148.

Champagnon J, Elmberg J, Guillemain M, Gauthier-Clerc M, and Lebreton J-D. 2012. Conspecifics can be aliens too: A review of effects of restocking practices in vertebrates. Journal for Nature Conservation 20:231-241.

Cunningham AA. 1996. Disease risks of wildlife translocations. Conservation Biology 10:349353.

Dalton S, Godwin S, Smith S, and Pereg L. 2010. Australian subtropical white syndrome: a transmissible, temperature-dependent coral disease. Marine and Freshwater Research 61:342-350.

Fogarty ND. 2012. Caribbean acroporid coral hybrids are viable across life history stages. Marine Ecology Progress Series 446:145-159.

PeerJ reviewing PDF | (v2014:03:1880:2:1:NEW 5 Aug 2014) 
600

601

602

603

604

605

606

607

608

609

610

611

612

613

614

615

616

617

618

619

620

621

622

623

624

625

626

627

628

629

630

631

632

633

634

635

636

637

638

639

640

641

642

643

644

645

646

647

648

Friedman CS, Andree KB, Beauchamp KA, Moore JD, Robbins TT, Shields JD, and Hedrick RP. 2000. 'Candidatus Xenohaliotis californiensis', a newly described pathogen of abalone, Haliotis spp., along the west coast of North America. International Journal of Systematic Bacteriololgy 50:847:855.

Friedman CS, and Finley CA. 2003. Anthropogenic introduction of the etiological agent of withering syndrome into northern California abalone populations via conservation efforts. Canadian Journal of Fisheries and Aquatic Sciences 60:1424-1431.

Fryer JL, and Lannan CN. 1994. Rickettsial and chlamydial infections of freshwater and marine fishes, bivalves, and crustaceans. Zoological Studies 33:95-107.

Gignoux-Wolfsohn S, Marks CJ, and Vollmer SV. 2012. White Band Disease transmission in the threatened coral, Acropora cervicornis. Scientific reports 2:804.

Gil-Agudelo DL, Smith GW, and Weil E. 2006. The white band disease type II pathogen in Puerto Rico. Revista Biologia Tropical 54:59-67.

Gladfelter WB. 1982. White-Band Disease in Acropora palmata : Implications for the structure and growth of shallow reefs. Bulletin of Marine Science 32:639-643.

Gladfelter WB, Gladfelter EH, Monahan RK, Ogden JC, and Dill RF. 1977. Coral destruction. Environmental Studies of Buck Island Reef National Monument, US National Park Service Report, $144 \mathrm{pp}$.

Hemond EM, and Vollmer SV.2010. Genetic diversity and connectivity in the threatened staghorn coral (Acropora cervicornis) in Florida. PLoS ONE 5:e8652.

Highsmith RC. 1982. Reproduction by fragmentation in corals. Marine Ecology Progress Series 7:207-226.

Hilborn R, and Eggers D. 2000. A review of the hatchery programs for pink salmon in Prince William Sound and Kodiak Island, Alaska. Transactions of the Americal Fisheries Society 129:333-350.

Hudson JH. 2000. First aid for massive corals infected with black band disease, Phormidium corallyticum: An underwater aspirator and post-treatment sealant to curtail reinfection. Diving for Science, AAUS 20th Symposium Proceedings:10-11.

IUCN. 2012. IUCN Red List of Threatened Species Version 2012.2. p www.iucnredlist.org.

Jagoe CH. 1996. Responses at the tissue level: Quantitative methods in histopathology applied to ecotoxicology. In: Newman MC, and Jagoe CH, eds. Ecotoxicology: A Hierarchical Treatment. Boca Raton, FL: Lewis Publishers.

Johnson ME, Lustic C, Bartels E, Baums IB, Gilliam DS, Larson L, Lirman D, Miller MW, Nedimyer K, and Schopmeyer S. 2011. Caribbean Acropora Restoration Guide: Best Practices for Propagation and Population Enhancement Arlington, VA.: The Nature Conservancy. p 54 .

Jones RJ. 1997. Changs in zooxanthellar densities and chlorophyll concentrations in corals during and after a bleaching event. Marine Ecology Progress Series 158:51-59.

Kline DI, and Vollmer SV.2011. White Band Disease (type I) of endangered Caribbean acroporid corals is caused by pathogenic bacteria. Scientific Reports 1:Article 7.

Knowlton N, Lang JC, Rooney MC, and Clifford P. 1981. When hurricanes kill corals: Evidence for delayed mortality in hurricane-damaged Jamaican staghorn corals. Nature 294:251252.

Lenihan H, Micheli F, Shelton S, and Peterson C. 1999. The influence of multiple environmental stressors on susceptibility to parasites: An experimental determination with oysters. Limnology and Oceanography 44:910-924.

Libro S, Kaluziak ST, and Vollmer SV. 2013. RNA-seq profiles of immune related genes in the staghorn coral Acropora cervicornis infected with White Band Disease. PLoS ONE 8:e81821.

PeerJ reviewing PDF | (v2014:03:1880:2:1:NEW 5 Aug 2014) 
649

650

651

652

653

654

655

656

657

658

659

660

661

662

663

664

665

666

667

668

669

670

671

672

673

674

675

676

677

678

679

680

681

682

683

684

685

686

687

688

689

690

691

692

693

694

695

696

697

Marks KW, and Lang JC. 2007. AGRRA Summary Products, version (10/2007). Available online $<$ http:wwwagrraorg/Release_2007-10/>.

Miller MW, and Williams DE. 2006. Coral disease outbreak at Navassa, a remote Caribbean island. Coral Reefs 26:97-101.

Noguchi H. 1926. Cultivation of rickettsia-like microorganisms from the Rocky Mountain spotted fever tick, Dermacentor andersoni. Jouranal Experimental Medicine 43:515-532.

Patterson KL, Porter JW, Ritchie KE, Polson SW, Mueller E, Peters EC, Santavy DL, and Smiths GW. 2002. The etiology of white pox, a lethal disease of the Caribbean elkhorn coral, Acropora palmata. Proceedings Of The National Academy Of Sciences USA 99:87258730.

Peters EC. 1984. A survey of cellular reactions to environmental stress and disease in Caribbean scleractinian corals. Helgo Meeresunters 37:113-137.

Peters EC, Oprandy JJ, and Yevich PP. 1983. Possible causal agent of "white band disease" in Caribbean acroporid corals. Journal of Invertebrate Pathology 41:394-396.

Peters EC, Price KL, and Borsay Horowitz DJ. 2005. Histological preparation of invertebrates for evaluating contaminant effects. In: Ostrander GK, ed. Techniques in Aquatic Toxicology Vol 2. Boca Raton, FL: Taylor \& Francis, 653-686.

Raymundo L, Couch C, and Harvell CD. 2008. Coral Disease Handbook: guidelines for assessment, monitoring \& management. St. Lucia, Queensland, Australia www.gefcoral.org: Coral Reef Targeted Research \& Capacity Building for Management.

Ritchie KB. 2006. Regulation of microbial populations by coral surface mucus and mucusassociated bacteria. Marine Ecology Progress Series 322:1-14.

Ritchie KB, and Smith GW. 1998. Type II white-band disease. Revista de Biologia Tropical 46:199-203.

Rogers C. 2010. Words matter: Recommendations for clarifying coral disease nomenclature and terminology. Diseases of Aquatic Organisms 91:167.

Ruiz-Moreno D, Willis BL, Page AC, Weil E, Cróquer A, Vargas-Angel B, Jordan-Garza AG, Jordán-Dahlgren E, Raymundo L, and Harvell CD. 2012. Global coral disease prevalence associated with sea temperature anomalies and local factors. Diseases of Aquatic Organisms 100:249-261.

Sainsbury AW, and Vaughan-Higgins RJ. 2012. Analyzing disease risks associated with translocations. Conservation Biology 26:442-452.

Schoepf V, Grottoli AG, Warner ME, Cai W-J, Melman TF, Hoadley KD, Pettay DT, Li Q, Xu H, Wang Y et al. . 2013. Coral energy reserves and calcification in a high-CO2 world at two temperatures. PLoS ONE 8:e75049. .

Shinn E. 1976. Coral reef recovery in Florida and the Persian Gulf. Environmental Geology 1:241-254.

Sun J, and Wu X. 2004. Histology, ultrastructure, and morphogenesis of a Rickettsia-like organism causing disease in the oyster Crassostrea ariakensis Gould. Journal of Invertebrate Pathology 86:77-86.

Sutherland KP, Porter JW, and Torres C. 2004. Disease and immunity in Caribbean and IndoPacific zooxanthellate corals. Marine Ecology Progress Series 266:273-302.

Upton SJ, and Peters EC. 1986. A new and unusual species of Coccidium (Apicomplexa: Agamococcidiorida from Caribbean scleractinian corals. Journal of Invertebrate Pathology 47:184-193.

Vollmer SV, and Kline DI. 2008. Natural disease resistance in threatened staghorn corals. PLoS ONE 3:e3718. doi:3710.1371/journal.pone.0003718.

Weis VM. 2008. Cellular mechanisms of Cnidarian bleaching: stress causes the collapse of symbiosis. Journal of Experimental Biology 211:3059-3066.

PeerJ reviewing PDF | (v2014:03:1880:2:1:NEW 5 Aug 2014) 
698 Williams DE, and Miller MW. 2005. Coral disease outbreak: pattern, prevalence, and 699 transmission in Acropora cervicornis. Marine Ecology Progress Series 301:119-128.

700 Work TM, and Aeby GS. 2011. Pathology of tissue loss (white syndrome) in Acropora spp. corals 701 from the Central Pacific. Journal of Invertebrate Pathology 197:127-131.

702 Work TM, and Aeby GS. 2014. Microbial aggregates within tissues infect a diversity of corals 703 throughout the Indo-Pacific. Marine Ecology Progress Series 500:1-9.

704 Young CN, Schopmeyer SA, and Lirman D. 2012. A review of reef restoration and coral 705 propagation using the threatened genus Acropora in the Caribbean and Western Atlantic. 706 Bulletin of Marine Science 88:1075-1098. 


\section{Figure Legends:}

708 Figure 1: Illustration of disease and predation conditions categorized in this study. A) Loss of 709 necrotic tissue from skeleton of A. palmata during WBD outbreak, Tague Bay, St. Croix, 1980 B)

710 Typical disease-affected colony with diffuse lesions of denuded skeleton, C) WBD-I, D) initial 711 stages of RTL, (E) Colony manifesting signs of both WBD-I (base) and RTL (tips), F) WBD-II 712 signs, G) fireworm predation with two older preyed tips (partially colonized by algal turfs)

713 visible, and $\mathrm{H}$ ) snail predation scar on basal portion of branch (removed snails indicated by 714 arrow).

715 Figure 2: Illustration of the treatments used in the mitigation trials. A) Excision (EX) of healthy 716 looking tips snipped from a nearby disease colony and re-attached to the reef, B) Epoxy band 717 (EB) surrounding the diseased tissue margin. One month later (C) this 'successful' EB replicate 718 shows no additional tissue loss and initial regrowth over the epoxy. Control treatments are 719 illustrated in Fig 1C and 1D.

720 Figure 3: Disease prevalence in Acropora cervicornis colonies in Wild (A and B) and Restored (C 721 and D) populations over two survey periods (May-Nov 2011 and May-Nov 2012). Dotted lines

722 indicate close passage of Tropical Storm Isaac in Aug 2012. Panels E and F show the 723 temperature records from the same sites and time periods.

724 Figure 4: Frequencies of cumulative partial mortality in tagged diseased colonies during the 2012 725 survey period before (A and B, Surveys 1-5) and after (C and D, Surveys 1-6) passage of Tropical

726 Storm Isaac at Restored and Wild sites. The bin labeled zero includes colonies that were 727 observed with disease signs but accumulated less partial mortality than could be resolved in 728 coarse visual estimates.

729 Figure 5: Results of experimental mitigation trials showing response in each year for Epoxy730 Band (EB), Excision (EX) and Control (C, cable tie placed around disease margin on a branch) 731 treatments as the percent of replicates showing continued tissue loss after one month. Number of 732 replicates is given above each bar. Chi-Squared Goodness of Fit tests indicate no significant 
733 difference in the proportions of the three treatments showing continued tissue loss when all

734 replicates across years are pooled.

735 Figure 6: Histology observations. A) Coenenchyme epidermis from apparently healthy Acropora 736 cervicornis branch tip, columnar mucocytes of surface body wall (large arrow), suspect RLOs in 737 gastrodermal mucocytes of basal body wall (small arrows), Giemsa. B) Mesenteries showing 738 sections through cnidoglandular bands (large arrow), H\&E. C) Apparently healthy staghorn 739 sample, epithelia lining gastrovascular canals with columnar calicoblasts having extensions of 740 plasmallema (large arrows and inset), H\&E. D) Section through tentacles (=T) and oral disc from 741 apparently healthy colony sample, mucocytes infected with suspect RLOs stain dark purple (large 742 arrow pointing to oral disc and inset), Giemsa. E) Cnidoglandular bands from apparently healthy 743 colony sample, suspect RLOs in mucocytes (large arrows) and mucocytes in the epithelium 744 (small arrows). F) Coenenchyme epidermis from A. cervicornis showing signs of RTL, note 745 atrophy of epithelium and loss of mucocytes (large arrow), suspect RLOs in gastrodermal 746 mucocytes of basal body wall (small arrows), Giemsa. G) Sections through mesenteries from 747 RTL-affected sample with degeneration (necrosis, lysing) and dissociation of cells of the 748 cnidoglandular bands, note pink-staining acidophilic granular gland cells are rounding up and 749 atrophied, ciliated cells and mucocytes are reduced in number compared to Fig. 6B, H\&E. H) 750 RTL-affected sample epithelia lining gastrovascular canals, severe atrophy of the calicodermis, 751 loss of calicoblasts from mesoglea (large arrows and inset); adjacent gastrodermis is swollen, 752 fragmented, and vacuolated compared to cuboidal cells in upper left corner of image, H\&E. I) 753 Suspect RLOs infecting gastrodermal cells (large arrows and inset) lining the mesenteries (= 754 MES) of an apparently healthy sample, Giemsa. J) High magnification of infected epidermal 755 mucocytes from apparently healthy sample, showing pleomorphic suspect RLOs (large arrow) 756 and mucocytes (small arrows, = MUC), Giemsa.

757 Figure 7: Histology parameter scores comparisons. A) Apparently healthy samples vs. diseased 758 samples. B) Successful vs unsuccessful mitigation treatment samples. C) Microscopic 759 characteristics of WBD vs. RTL samples. 


\section{Table 1 (on next page) \\ Comparison of existing Acropora cervicornis disease descriptions}

Comparison of field manifestations of lesions seen in A. cervicornis and morphologic diagnoses. See Work and Aeby ( 2006 ) and Galloway et al. ( 2007 ) for definitions of terms. 


\begin{tabular}{|c|c|c|c|c|c|c|c|}
\hline $\begin{array}{l}\text { Field } \\
\text { Name }\end{array}$ & $\begin{array}{l}\text { Tissue } \\
\text { Loss } \\
\text { Type } \\
\end{array}$ & $\begin{array}{l}\text { Location } \\
\text { of Lesion } \\
\text { on } \\
\text { Colony* }\end{array}$ & $\begin{array}{l}\text { Lesion } \\
\text { Margin } \\
\text { Appearance }\end{array}$ & $\begin{array}{l}\text { Lesion } \\
\text { Shape } \\
\text { And Size }\end{array}$ & $\begin{array}{l}\text { Lesion } \\
\text { Number } \\
\text { and Color }\end{array}$ & Lesion Progression & $\begin{array}{l}\text { Morphologic } \\
\text { Diagnosis }\end{array}$ \\
\hline $\begin{array}{l}\text { White- } \\
\text { band } \\
\text { disease } \\
\text { type I } \\
\left(\text { WBD-I }{ }^{1}\right.\end{array}$ & Acute to & $\begin{array}{l}\text { Base or } \\
\text { middle of } \\
\text { branch, } \\
\text { encircling } \\
\text { branch }\end{array}$ & $\begin{array}{l}\text { Distinct areas } \\
\text { of tissue loss, } \\
\text { smooth to } \\
\text { serpiginous } \\
\text { margin, tissue } \\
\text { tan to brown } \\
\text { (due to } \\
\text { symbiotic } \\
\text { algae pigment- } \\
\text { ation) }\end{array}$ & $\begin{array}{l}\text { Band of } \\
\text { intact bare } \\
\text { skeleton, } \\
\text { well- } \\
\text { different- } \\
\text { iated from } \\
\text { more distal } \\
\text { skeleton }\end{array}$ & $\begin{array}{l}\text { Focal to } \\
\text { multifocal } \\
\text { to diffuse, } \\
\text { white } \\
\text { (denuded } \\
\text { skeleton), } \\
\text { normally } \\
\text { pigmented } \\
\text { tissue } \\
\text { margin }\end{array}$ & $\begin{array}{l}\text { White band typically } 2-10 \\
\text { cm wide; rate of tissue loss } \\
\text { usually a few mm per day } \\
\text { but can vary or stop; at } \\
\text { branch bifurcation tissue } \\
\text { loss continues on both } \\
\text { branches at about the same } \\
\text { rate; freshly denuded } \\
\text { skeleton grades into green } \\
\text { to brown algal growth on } \\
\text { the skeleton, first visible } \\
\text { after 5-7 days and } \\
\text { becoming increasingly } \\
\text { dense with time }\end{array}$ & $\begin{array}{l}\text { Severe, basal to } \\
\text { mid-branch } \\
\text { band, diffuse, } \\
\text { acute tissue loss, } \\
\text { polyp, } \\
\text { coenenchyme }\end{array}$ \\
\hline $\begin{array}{l}\text { White- } \\
\text { band } \\
\text { disease } \\
\text { type II } \\
(\text { WBD-II })^{2}\end{array}$ & $\begin{array}{l}\text { Acute } \\
\text { subacute }\end{array}$ & $\begin{array}{l}\text { Tip or base } \\
\text { of branch, } \\
\text { encircling } \\
\text { branch }\end{array}$ & $\begin{array}{l}\text { Distinct areas } \\
\text { of tissue loss, } \\
\text { smooth } \\
\text { margin, } \\
2-20 \mathrm{~cm} \text { wide } \\
\text { band of } \\
\text { bleaching } \\
\text { tissue (loss of } \\
\text { brown algal } \\
\text { pigmentation) } \\
\text { between tissue } \\
\text { loss margin } \\
\text { and normally } \\
\text { pigmented } \\
\text { tissue }\end{array}$ & $\begin{array}{l}\text { Band of } \\
\text { intact bare } \\
\text { skeleton, } \\
\text { well- } \\
\text { differentiated } \\
\text { from more } \\
\text { distal } \\
\text { skeleton, } \\
\text { developing } \\
\text { green to } \\
\text { brown algal } \\
\text { growth }\end{array}$ & $\begin{array}{l}\text { Focal to } \\
\text { multifocal, } \\
\text { white } \\
\text { (denuded } \\
\text { skeleton), } \\
\text { bleaching } \\
\text { tissue } \\
\text { margin }\end{array}$ & $\begin{array}{l}\text { White band typically } 2-10 \\
\text { cm wide; rate of tissue loss } \\
\text { usually a few mm per day; } \\
\text { bleaching margin tissue } \\
\text { disappears, normally } \\
\text { pigmented tissue starts } \\
\text { bleaching; however, } \\
\text { bleaching margin tissue } \\
\text { may also disappear and } \\
\text { then the normally } \\
\text { pigmented tissue } \\
\text { disappears, as in WBD-I; } \\
\text { freshly denuded skeleton } \\
\text { grades into green to brown } \\
\text { algal growth on the }\end{array}$ & $\begin{array}{l}\text { Severe, basal, } \\
\text { band, diffuse, } \\
\text { acute tissue loss, } \\
\text { bleaching } \\
\text { margin, } \\
\text { polyp, } \\
\text { coenenchyme }\end{array}$ \\
\hline
\end{tabular}




\begin{tabular}{|c|c|c|c|c|c|c|c|}
\hline & & & & & & $\begin{array}{l}\text { skeleton, first visible after } \\
5-7 \text { days and becoming } \\
\text { increasingly dense with } \\
\text { time }\end{array}$ & \\
\hline $\begin{array}{l}\text { Rapid } \\
\text { Tissue } \\
\text { Loss } \\
(\text { RTL) }\end{array}$ & 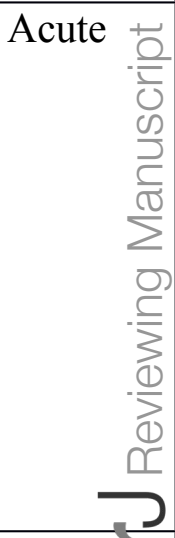 & $\begin{array}{l}\text { Basal, } \\
\text { medial, or } \\
\text { colony- } \\
\text { wide, } \\
\text { partially to } \\
\text { completely } \\
\text { encircling } \\
\text { branch }\end{array}$ & $\begin{array}{l}\text { Distinct areas } \\
\text { of tissue loss, } \\
\text { undulating to } \\
\text { serpiginous } \\
\text { margin, tan to } \\
\text { brown tissue, } \\
\text { sloughing }\end{array}$ & $\begin{array}{l}\text { Irregularly } \\
\text { shaped areas } \\
\text { of intact bare } \\
\text { skeleton }\end{array}$ & $\begin{array}{l}\text { Focal to } \\
\text { multifocal } \\
\text { and } \\
\text { coalescing } \\
\text { to diffuse, } \\
\text { white } \\
\text { (denuded } \\
\text { skeleton) }\end{array}$ & $\begin{array}{l}\text { Intact bare skeleton } \\
\text { appears quickly along } \\
\text { branches, new lesions may } \\
\text { coalesce; rate of tissue loss } \\
\text { usually cm per day; } \\
\text { denuded skeleton develops } \\
\text { green to brown algal } \\
\text { growth that becomes } \\
\text { uniformly visible after 5-7 } \\
\text { days covering entire } \\
\text { denuded area }\end{array}$ & $\begin{array}{l}\text { Severe, basal to } \\
\text { complete, band } \\
\text { or irregular, } \\
\text { diffuse, acute to } \\
\text { subacute tissue } \\
\text { loss, polyp, } \\
\text { coenenchyme }\end{array}$ \\
\hline $\begin{array}{l}\text { Fireworm } \\
(H . \\
\text { carunculat } \\
a) \\
\text { predation } \\
\text { feeding } \\
\text { scars }^{1}\end{array}$ & Acute (1) & $\begin{array}{l}\text { Apical } 1 \text { to } \\
5 \mathrm{~cm} \text { of } \\
\text { branch, but } \\
\text { not } \\
\text { extending } \\
\text { beyond a } \\
\text { branch } \\
\text { bifurcation }\end{array}$ & $\begin{array}{l}\text { Distinct areas } \\
\text { of tissue loss } \\
\text { encircling apex } \\
\text { of branch, } \\
\text { smooth to } \\
\text { serpiginous } \\
\text { margins, tissue } \\
\text { tan to brown }\end{array}$ & $\begin{array}{l}\text { Intact bare } \\
\text { skeleton, tip } \\
\text { of branch, } \\
\text { developing } \\
\text { green to } \\
\text { brown algal } \\
\text { growth }\end{array}$ & $\begin{array}{l}\text { Focal to } \\
\text { diffuse, } \\
\text { white } \\
\text { (denuded } \\
\text { skeleton) }\end{array}$ & $\begin{array}{l}\text { None, denuded skeleton } \\
\text { develops uniform green to } \\
\text { brown algal growth }\end{array}$ & $\begin{array}{l}\text { Severe, focal, } \\
\text { branch tip, acute } \\
\text { tissue loss, } \\
\text { polyp, } \\
\text { coenenchyme }\end{array}$ \\
\hline $\begin{array}{l}\text { Snail }(C . \\
\text { abberviata } \\
\text { ) predation } \\
\text { feeding } \\
\text { scars }^{1}\end{array}$ & Acute & $\begin{array}{l}\text { Colony } \\
\text { base, } \\
\text { skeletal- } \\
\text { tissue } \\
\text { margin } \\
\text { inward and } \\
\text { vertically }\end{array}$ & $\begin{array}{l}\text { Distinct areas } \\
\text { of tissue loss, } \\
\text { smooth to } \\
\text { serpiginous } \\
\text { rounded or } \\
\text { scalloped } \\
\text { margins, tissue } \\
\text { tan to brown }\end{array}$ & $\begin{array}{l}\text { Intact bare } \\
\text { skeleton, } \\
\text { usually } \\
\text { adjacent to } \\
\text { one or more } \\
\text { Coralliophil } \\
\text { a abbreviata }\end{array}$ & $\begin{array}{l}\text { Focal or } \\
\text { multifocal, } \\
\text { white } \\
\text { (denuded } \\
\text { skeleton) }\end{array}$ & $\begin{array}{l}\text { None, denuded skeleton } \\
\text { gradually colonized by } \\
\text { green to brown algal } \\
\text { growth }\end{array}$ & $\begin{array}{l}\text { Severe, diffuse, } \\
\text { basal, acute } \\
\text { tissue loss, } \\
\text { polyp, } \\
\text { coenenchyme }\end{array}$ \\
\hline
\end{tabular}

*First lesion on all of these may be a single small focus of acute tissue loss, either at the base or in the middle of a branch, lesion enlargement pattern then varies. 
${ }^{1}$ Illustrated in Williams et al. (2006) but only for A.palmata

${ }^{2}$ Described in Ritchie and Smith (1998)

${ }^{3}$ Described in Williams and Miller (2005); described but not named in Bak and Criens (1981)

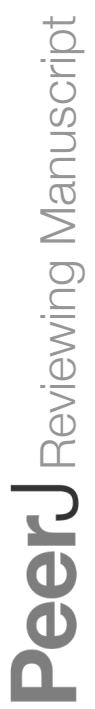




\section{Table 2 (on next page)}

Characteristics of study sites/populations and mitigation experiment in the upper Florida Keys.

Number of genets indicates number of Acropora cervicornis multi-locus genotypes (based on seven microsatellite markers (Baums et al. 2009, Baums et al. 2010) ) within the surveyed populations at each site. Distribution of experimental replicates for the mitigation experiment among sites and years is summarized in the last two columns. UNK= Unknown, $\mathrm{C}=\mathrm{Control}$, $\mathrm{EB}=$ Epoxy Band, $\mathrm{EX}=$ Excision . 


\begin{tabular}{|c|c|c|c|c|c|c|c|}
\hline & $\begin{array}{l}\text { Colony } \\
\text { Origin }\end{array}$ & $\begin{array}{l}\text { Site } \\
\text { Type }\end{array}$ & $\begin{array}{l}\text { \# of } \\
\text { Genets }\end{array}$ & Coordinates & $\begin{array}{l}\text { Dept } \\
\text { h (m) }\end{array}$ & $\begin{array}{l}\# 2011 \\
\text { replicates } \\
(\mathrm{C} / \mathrm{EB} / \mathrm{EX})\end{array}$ & $\begin{array}{l}\text { \# } 2012 \\
\text { replicates } \\
(\mathrm{C} / \mathrm{EB} / \mathrm{EX})\end{array}$ \\
\hline Molasses & Nursery & Restored & 3 & $\begin{array}{l}25^{\circ} 00.60^{\prime} \mathrm{N} \\
80^{\circ} 22.37^{\prime} \mathrm{W}\end{array}$ & $8-10$ & $2 / 8 / 6$ & $1 / 1 / 0$ \\
\hline Aquarius & $\begin{array}{l}\text { Transplant } \\
\text { \& Nursery }\end{array}$ & Restored & 11 & $\begin{array}{l}24057.20^{\prime} \mathrm{N} \\
80 \mathrm{o} 27.15^{\prime} \mathrm{W}\end{array}$ & 14 & $9 / 6 / 3$ & NA \\
\hline $\begin{array}{l}\text { Conch } \\
\text { Shallow }\end{array}$ & Transplant & Restored & 14 & $\begin{array}{l}24^{\circ} 57.08^{\prime} \mathrm{N} \\
80^{\circ} 27.59^{\prime} \mathrm{W}\end{array}$ & 6 & $1 / 1 / 1$ & $4 / 4 / 5$ \\
\hline French & Nursery & Restored & 3 & $\begin{array}{l}25^{\circ} 07.31^{\prime} \mathrm{N} \\
80^{\circ} 17.85^{\prime} \mathrm{W}\end{array}$ & 10 & $5 / 3 / 4$ & $6 / 5 / 1$ \\
\hline $\begin{array}{l}\text { KL Dry } \\
\text { Rocks }\end{array}$ & Nursery & Restored & 3 & $\begin{array}{l}25^{\circ} 07.45^{\prime} \mathrm{N} \\
80^{\circ} 17.84^{\prime} \mathrm{W}\end{array}$ & 6 & NA & $3 / 3 / 4$ \\
\hline Pickles & Nursery & Restored & 3 & $\begin{array}{l}24^{\circ} 59.30^{\prime} \mathrm{N} \\
80^{\circ} 24.74^{\prime} \mathrm{W}\end{array}$ & $8-10$ & $0 / 1 / 1$ & NA \\
\hline $\begin{array}{l}\text { Tav Patch } \\
\text { A }\end{array}$ & Wild & Wild & UNK* & $\begin{array}{l}24^{\circ} 59.23^{\prime} \mathrm{N} \\
80^{\circ} 27.17^{\prime} \mathrm{W}\end{array}$ & 6 & $\mathrm{NA}$ & NA \\
\hline $\begin{array}{l}\text { Tav Patch } \\
\text { B }\end{array}$ & Wild & Wild & UNK & $\begin{array}{l}24^{\circ} 59.24^{\prime} \mathrm{N} \\
80^{\circ} 27.16^{\prime} \mathrm{W}\end{array}$ & 6 & NA & NA \\
\hline $\begin{array}{l}\text { Little } \\
\text { Conch }\end{array}$ & Wild & Wild & UNK & $\begin{array}{l}24^{\circ} 56.78^{\prime} \mathrm{N} \\
80^{\circ} 28.21^{\prime} \mathrm{W}\end{array}$ & 6 & $\mathrm{NA}$ & $10 / 10 / 2$ \\
\hline $\begin{array}{l}\text { CRF } \\
\text { Nursery }\end{array}$ & & Nursery & $>20$ & $\begin{array}{l}24^{\circ} 59^{\prime} \mathrm{N} \\
80^{\circ} 26^{\prime} \mathrm{W}\end{array}$ & 11 & NA & NA \\
\hline
\end{tabular}

*Previous haphazard genotype sampling at this site yielded 6 unique genets in 20 sampled colonies (Miller \& Baums, unpubl) 


\title{
Table 3 (on next page)
}

Disease incidence in 2012

\author{
Survey intervals (dates and duration in weeks), incidence, and proportion of colonies that \\ remained unaffected by disease for the population of tagged colonies $(n=20)$ at each site \\ throughout the 2012 sampling period. Incidence is expressed as the proportion of new cases \\ observed during each survey interval (i.e., diseased tagged colonies observed without \\ disease in the previous survey) standardized per week. Shading is (arbitrarily) scaled with \\ incidence value with gradually darker shading indicating higher incidence (cutoff levels of \\ $0.01,0.025,0.05,0.1$ and 0.15$)$. Tropical Storm Isaac passed during Interval V.
}




\begin{tabular}{|c|c|c|c|c|c|c|c|}
\hline & $\begin{array}{l}\text { Interval } \\
\text { Dates } \\
\text { (\#weeks) }\end{array}$ & $\begin{array}{c}I \\
5 / 15- \\
6 / 2 \\
(2.71) \\
\end{array}$ & $\begin{array}{c}I I \\
6 / 2- \\
6 / 30 \\
(4.00) \\
\end{array}$ & $\begin{array}{c}\text { III } \\
6 / 30-7.23 \\
(3.29) \\
\end{array}$ & $\begin{array}{c}\text { IV } \\
7 / 23-8 / 15 \\
(3.29) \\
\end{array}$ & $\begin{array}{c}V \\
8 / 15-9 / 10 \\
(3.71)\end{array}$ & Unaffected \\
\hline \multirow{5}{*}{$\begin{array}{l}\text { D } \\
\frac{d}{0} \\
\stackrel{0}{0} \\
\stackrel{0}{\alpha}\end{array}$} & $\begin{array}{l}\text { Conch } \\
\text { Shallow }\end{array}$ & 0.018 & 0.000 & 0.000 & 0.064 & 0.126 & 0.400 \\
\hline & Pickles & 0.000 & 0.025 & 0.000 & 0.000 & 0.094 & 0.400 \\
\hline & Molasses & 0.037 & 0.025 & 0.000 & 0.016 & 0.000 & 0.800 \\
\hline & French & 0.000 & 0.050 & 0.046 & 0.076 & 0.075 & 0.250 \\
\hline & $\begin{array}{l}\text { KL Dry } \\
\text { Rocks }\end{array}$ & 0.018 & 0.088 & 0.000 & 0.015 & 0.184 & 0.150 \\
\hline \multirow{3}{*}{ 은 } & $\begin{array}{l}\text { Little } \\
\text { Conch }\end{array}$ & 0.037 & 0.063 & 0.046 & 0.076 & 0.099 & 0.000 \\
\hline & $\begin{array}{c}\text { Tav Patch } \\
A\end{array}$ & 0.018 & 0.013 & 0.000 & 0.000 & 0.038 & 0.800 \\
\hline & $\begin{array}{c}\text { Tav Patch } \\
\text { B }\end{array}$ & 0.018 & 0.000 & 0.016 & 0.015 & 0.058 & 0.700 \\
\hline
\end{tabular}




\title{
Table 4(on next page)
}

Histopathology summary

\author{
Summary statistics for histopathological observations on all apparently healthy $(n=21)$, \\ diseased $(n=11)$, and mitigation treatment samples $(n=11)$. Condition scores applied were \\ $0=$ Excellent, $1=$ Very Good, 2=Good, 3=Fair, 4=Poor, $5=$ Very Poor; scoring of severity or \\ intensity of tissue changes from normal were $0=$ Within Normal Limits, $1=$ Minimal, $2=$ Mild, \\ $3=$ Moderate, $4=$ Marked, $5=$ Severe.
}




\begin{tabular}{|c|c|c|c|c|c|c|c|c|c|}
\hline Parameter & \multicolumn{3}{|c|}{ Apparently Healthy } & \multicolumn{3}{|c|}{ Characterization Diseased } & \multicolumn{3}{|c|}{ Mitigation Treatments } \\
\hline Assigned Scores & Mean & St.Dev. & Range & Mean & St.Dev. & Range & Mean & St.Dev. & Range \\
\hline General Condition (100x) & 1.6 & 0.7 & $1-3$ & 4.5 & 0.5 & $3-5$ & 4.4 & 0.7 & $3-5$ \\
\hline Zooxanthellae (100x) & 1.2 & 0.5 & $0-2$ & 3.6 & 0.4 & $3-4$ & 3.4 & 0.3 & $3-4$ \\
\hline $\begin{array}{l}\text { Epidermal Mucocytes } \\
\text { Condition }\end{array}$ & 1.7 & 0.5 & $1-2$ & 4.3 & 0.5 & $3-5$ & 4.3 & 0.6 & $3-5$ \\
\hline $\begin{array}{l}\text { Mesenterial Filamerip } \\
\text { Mucocytes }\end{array}$ & 2.7 & 1.1 & $1-5$ & 4.4 & 0.7 & $3-5$ & 4.2 & 0.9 & $2-5$ \\
\hline $\begin{array}{l}\text { Degeneration Cnidoglandular } \\
\text { Bands }\end{array}$ & 1.5 & 1.3 & $0-5$ & 4.3 & 1.0 & $2-5$ & 3.8 & 1.3 & $2-5$ \\
\hline $\begin{array}{l}\text { Dissociation Mesenterial } \\
\text { Filaments }\end{array}$ & 0.5 & 0.9 & $0-3$ & 2.8 & 1.5 & $0-5$ & 1.9 & 1.2 & $0.2-3.7$ \\
\hline Costal Tissue Loss d & 0.3 & 0.5 & $0-1$ & 3.5 & 1.3 & $1-5$ & 3.2 & 1.4 & $0.9-4.8$ \\
\hline Calicodermis Condition & 1.4 & 0.6 & $1-3$ & 4.0 & 0.7 & $2-5$ & 3.8 & 0.9 & $2.1-4.9$ \\
\hline Bacterial Aggregates & 0.0 & 0.0 & $0-0$ & 0.0 & 0.0 & $0-0$ & 0.0 & 0.0 & $0-0$ \\
\hline Epidermal RLOs & 3.2 & 0.6 & $2-4$ & 3.6 & 0.5 & $3-4$ & 3.4 & 0.5 & $2.5-4$ \\
\hline Filament RLOs & 2.8 & 0.5 & $2-4$ & 2.8 & 1.2 & $1-5$ & 2.9 & 0.9 & $2-5$ \\
\hline \multicolumn{10}{|c|}{ Percent Affected (Presence/Absence) } \\
\hline Coccidia & \multicolumn{3}{|c|}{10} & \multicolumn{3}{|c|}{14} & \multicolumn{3}{|c|}{10} \\
\hline Calicodermis Repair & \multicolumn{3}{|c|}{0} & \multicolumn{3}{|c|}{43} & \multicolumn{3}{|c|}{33} \\
\hline Necrotic Cell Spherules & \multicolumn{3}{|c|}{0} & \multicolumn{3}{|c|}{33} & \multicolumn{3}{|c|}{33} \\
\hline Zooxanthellate Ciliates & \multicolumn{3}{|c|}{0} & \multicolumn{3}{|c|}{24} & \multicolumn{3}{|c|}{24} \\
\hline Non-zooxanthellate Ciliates & \multicolumn{3}{|c|}{0} & \multicolumn{3}{|c|}{10} & \multicolumn{3}{|c|}{14} \\
\hline Oocytes & \multicolumn{3}{|c|}{10} & \multicolumn{3}{|c|}{10} & \multicolumn{3}{|c|}{5} \\
\hline Spermaries & \multicolumn{3}{|c|}{0} & \multicolumn{3}{|c|}{0} & \multicolumn{3}{|c|}{0} \\
\hline
\end{tabular}




\section{Figure 1}

Illustration of disease and predation conditions categorized in this study
A) Loss of necrotic tissue from skeleton of $A$. palmata during WBD outbreak, Tague Bay, St. Croix, 1980 B) Typical disease-affected colony with diffuse lesions of denuded skeleton, C) WBD-I, D) initial stages of RTL, (E) Colony manifesting signs of both WBD-I (base) and RTL (tips), F) WBD-II signs, G) fireworm predation with two older preyed tips (partially colonized by algal turfs) visible, and $\mathrm{H}$ ) snail predation scar on basal portion of branch (removed snails indicated by arrow) 

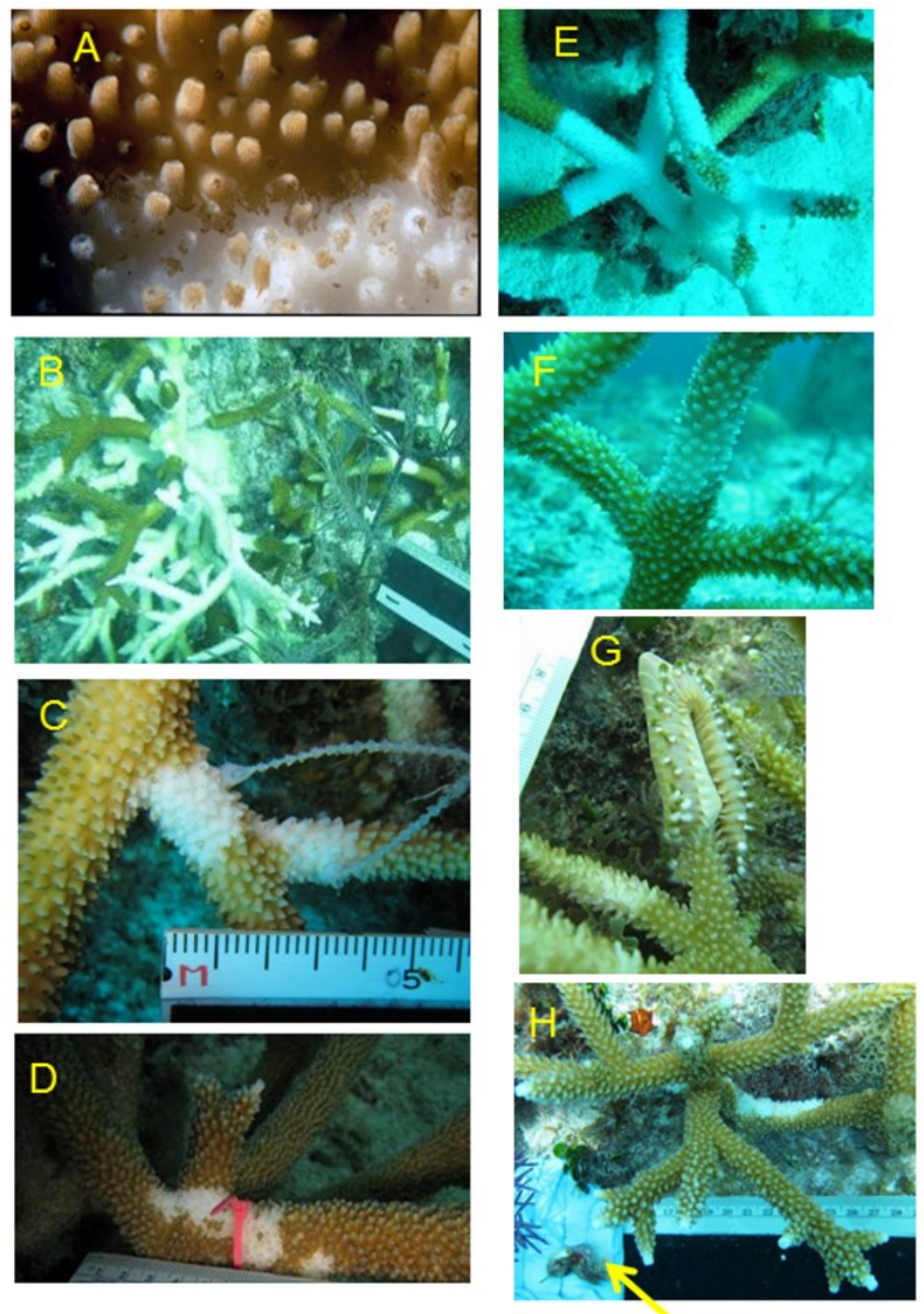


\section{Figure 2}

Illustration of the treatments used in mitigation trials

A) Excision (EX) of healthy looking tips snipped from a nearby disease colony and reattached to the reef, B) Epoxy band (EB) surrounding the diseased tissue margin. One month later (C) this 'successful' EB replicate shows no additional tissue loss and initial regrowth over the epoxy. Control treatments are illustrated in Fig $1 \mathrm{C}$ and $1 \mathrm{D}$. 

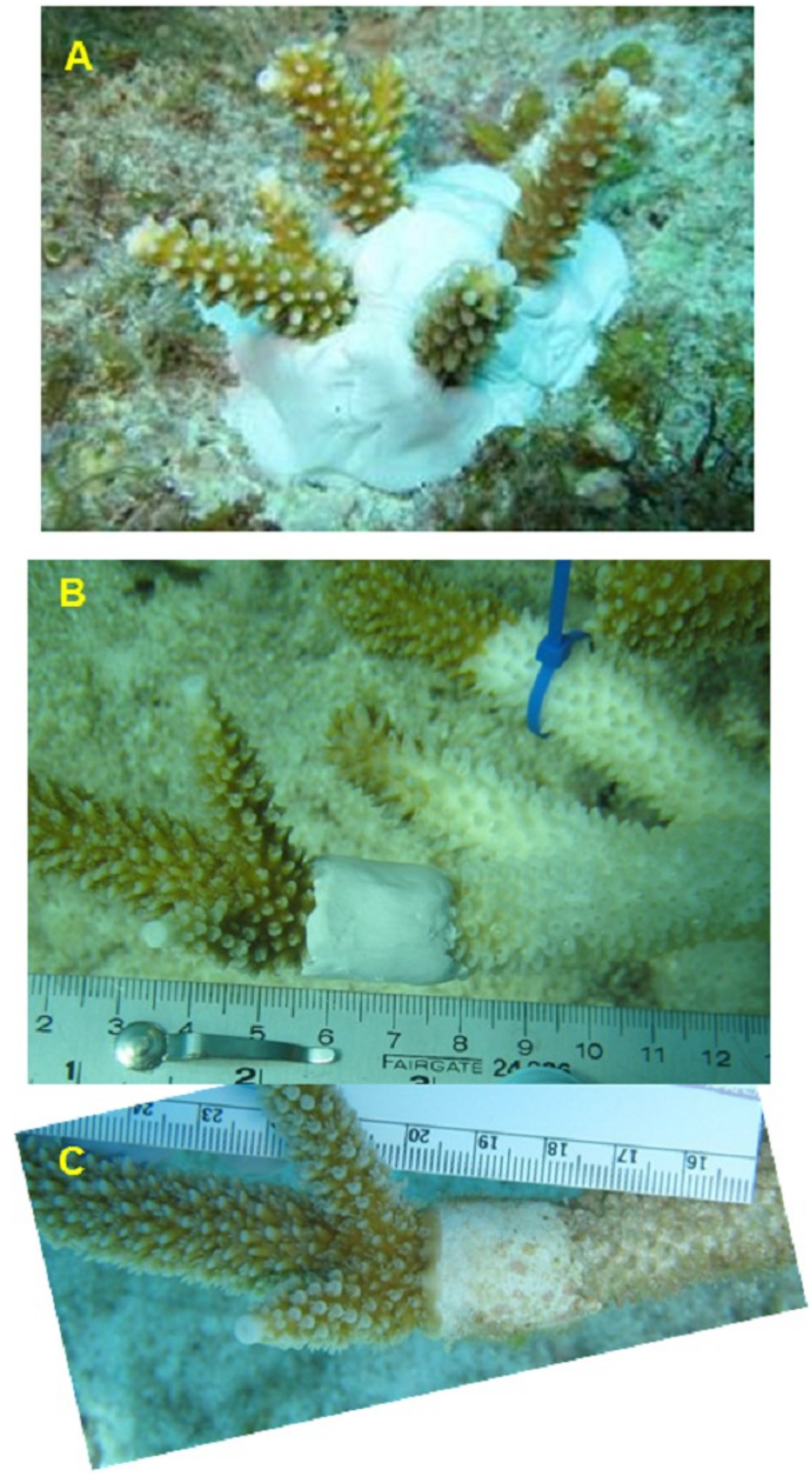


\section{Figure 3}

Disease prevalence and temperature

Disease prevalence in Acropora cervicornis colonies in Wild ( $A$ and $B$ ) and Restored ( $C$ and D) populations over two survey periods (May-Nov 2011 and May-Nov 2012). Dotted lines indicate close passage of Tropical Storm Isaac in Aug 2012. Panels E and F show the temperature records from the same sites and time periods. 

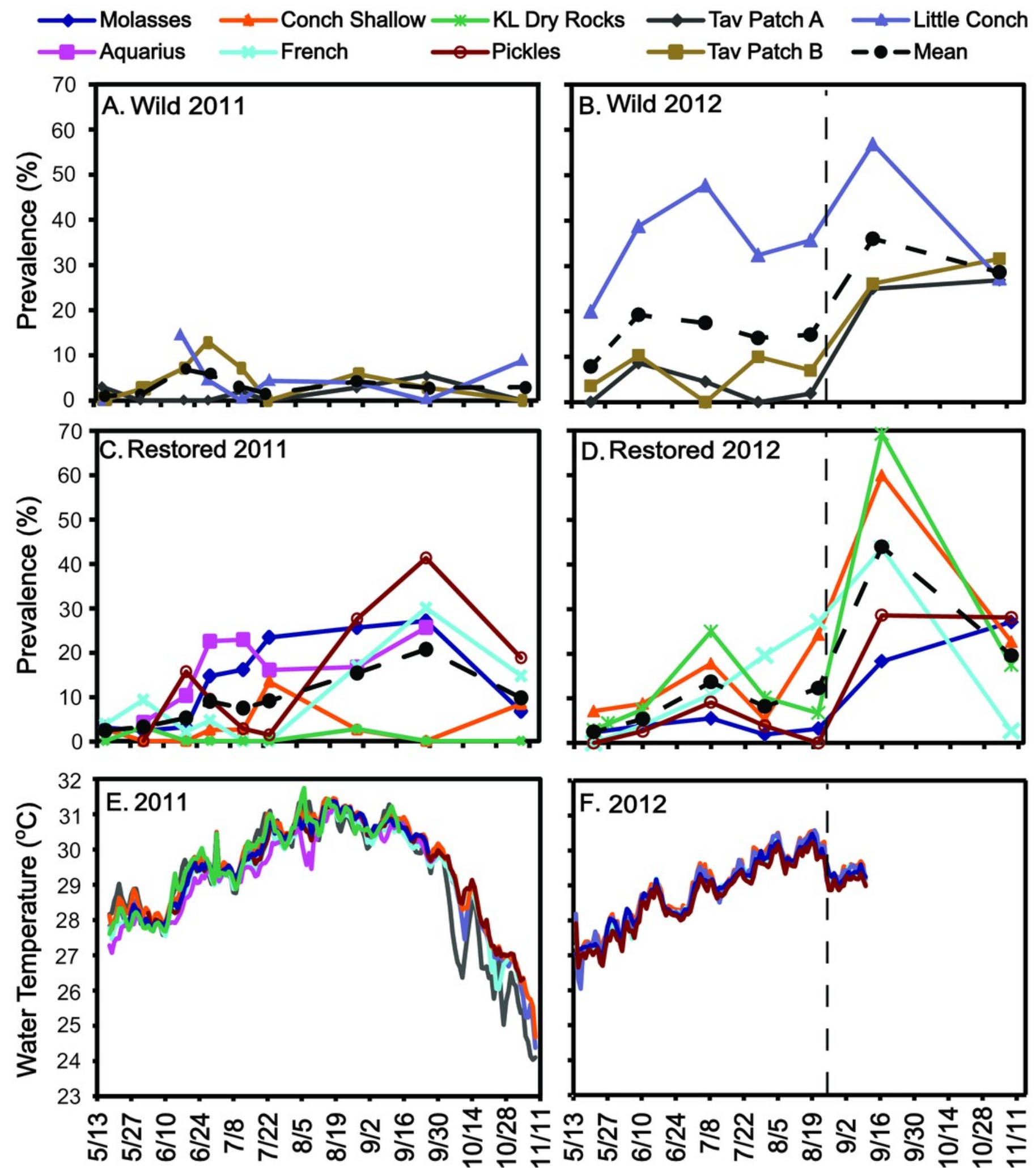


\section{Figure 4}

Partial mortality in diseased colonies

Frequencies of cumulative partial mortality in tagged diseased colonies during the 2012 survey period before ( $A$ and $B$, Surveys $1-5)$ and after ( $C$ and $D$, Surveys 1-6) passage of Tropical Storm Isaac at Restored and Wild sites. The bin labeled zero includes colonies that were observed with disease signs but accumulated less partial mortality than could be resolved in coarse visual estimates.
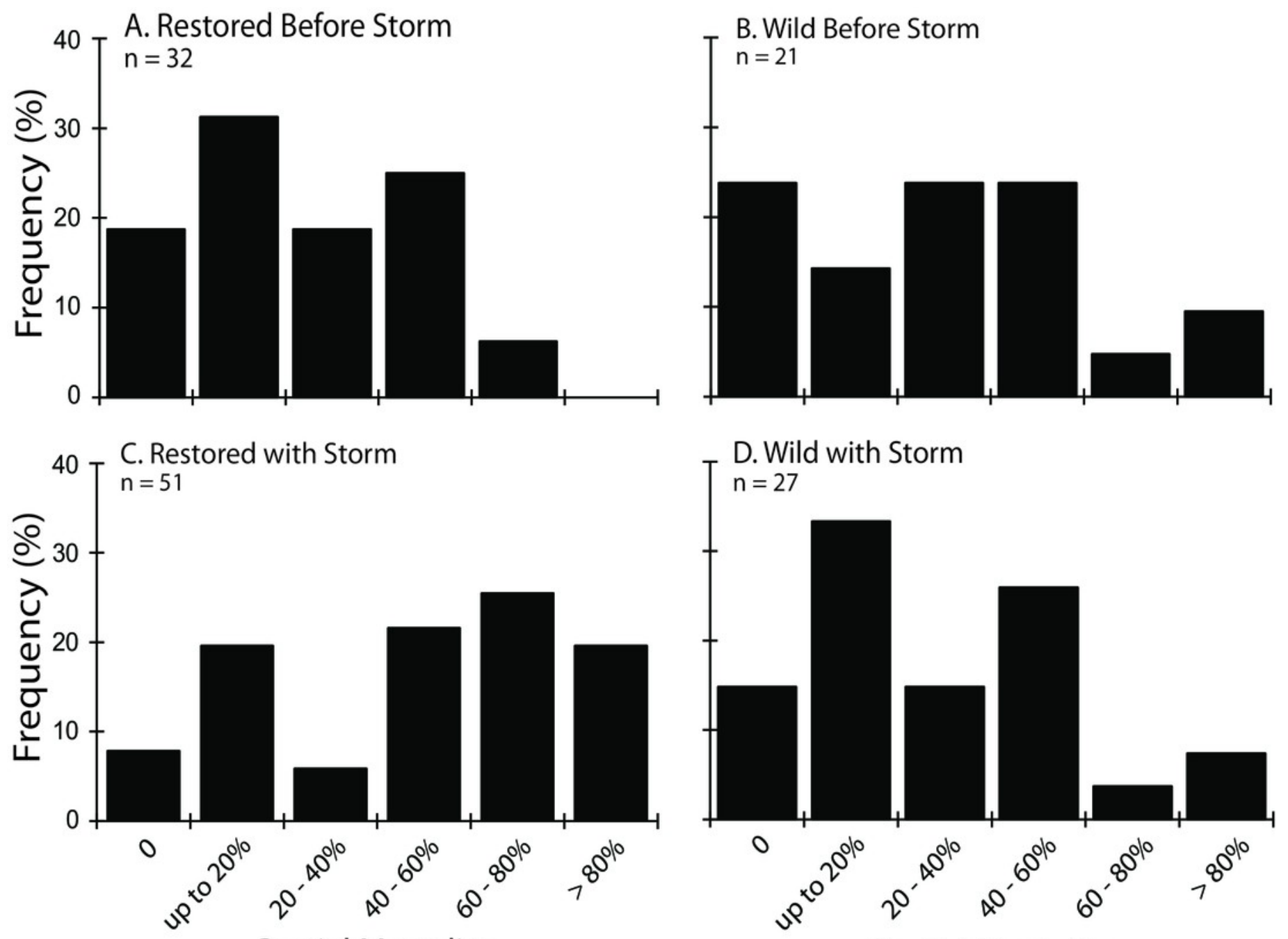

Partial Mortality

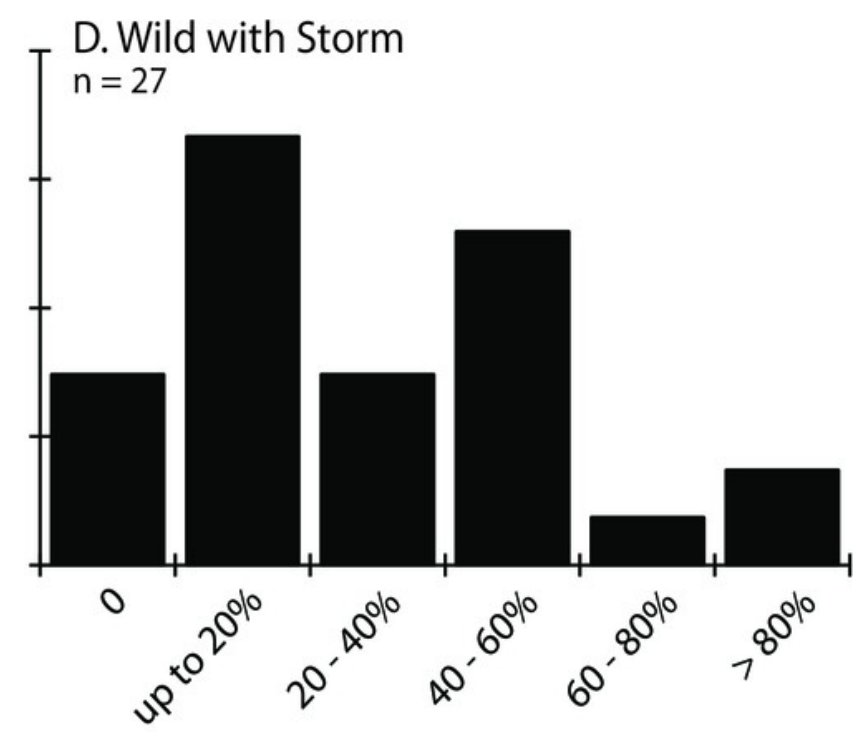

Partial Mortality 


\section{Figure 5}

Mitigation experiment

Results of experimental mitigation trials showing response in each year for Epoxy-Band (EB), Excision (EX) and Control (C, cable tie placed around disease margin on a branch) treatments as the percent of replicates showing continued tissue loss after one month.

Number of replicates is given above each bar. Chi-Squared Goodness of Fit tests indicate no significant difference in the proportions of the three treatments showing continued tissue loss when all replicates across years are pooled.

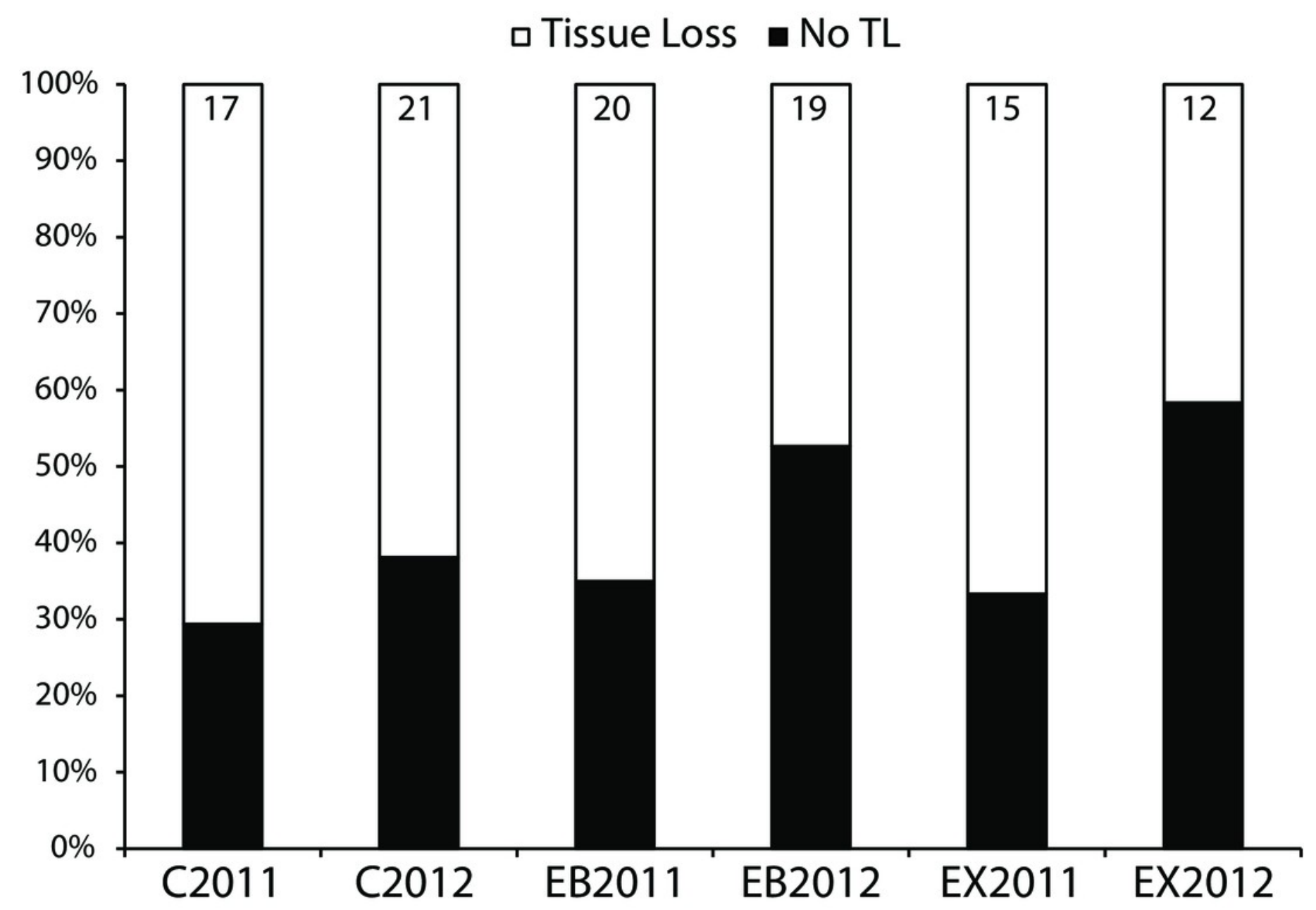




\section{Figure 6}

Histology observations

A) Coenenchyme epidermis from apparently healthy Acropora cervicornis branch tip, columnar mucocytes of surface body wall (large arrow), suspect RLOs in gastrodermal mucocytes of basal body wall (small arrows), Giemsa. B) Mesenteries showing sections through cnidoglandular bands (large arrow), H\&E. C) Apparently healthy staghorn sample, epithelia lining gastrovascular canals with columnar calicoblasts having extensions of plasmallema (large arrows and inset), H\&E. D) Section through tentacles $(=T)$ and oral disc from apparently healthy colony sample, mucocytes infected with suspect RLOs stain dark purple (large arrow pointing to oral disc and inset), Giemsa. E) Cnidoglandular bands from apparently healthy colony sample, suspect RLOs in mucocytes (large arrows) and mucocytes in the epithelium (small arrows). F) Coenenchyme epidermis from A. cervicornis showing signs of RTL, note atrophy of epithelium and loss of mucocytes (large arrow), suspect RLOs in gastrodermal mucocytes of basal body wall (small arrows), Giemsa. G) Sections through mesenteries from RTL-affected sample with degeneration (necrosis, lysing) and dissociation of cells of the cnidoglandular bands, note pink-staining acidophilic granular gland cells are rounding up and atrophied, ciliated cells and mucocytes are reduced in number compared to Fig. 6B, H\&E. H) RTL-affected sample epithelia lining gastrovascular canals, severe atrophy of the calicodermis, loss of calicoblasts from mesoglea (large arrows and inset); adjacent gastrodermis is swollen, fragmented, and vacuolated compared to cuboidal cells in upper left corner of image, H\&E. I) Suspect RLOs infecting gastrodermal cells (large arrows and inset) lining the mesenteries (= MES) of an apparently healthy sample, Giemsa. J) High magnification of infected epidermal mucocytes from apparently healthy sample, showing pleomorphic suspect RLOs (large arrow) and mucocytes (small arrows, = MUC), Giemsa 


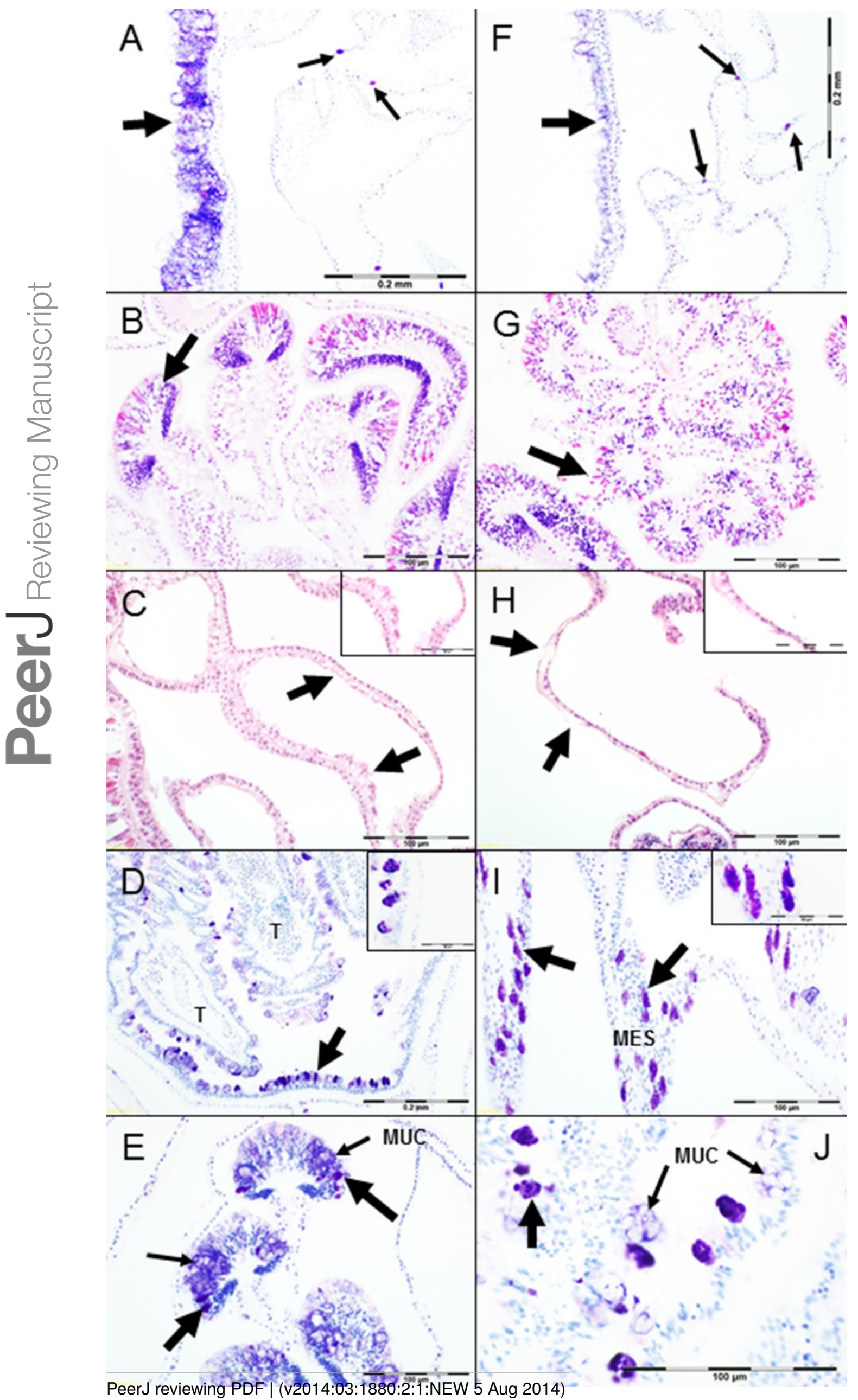




\section{Figure 7}

Histology parameter scores comparisons

A) Apparently healthy samples vs. diseased samples. B) Successful vs unsuccessful mitigation treatment samples. C) Microscopic characteristics of WBD vs. RTL samples. 


\section{A Characteristics of Apparently Healthy vs. Diseased}

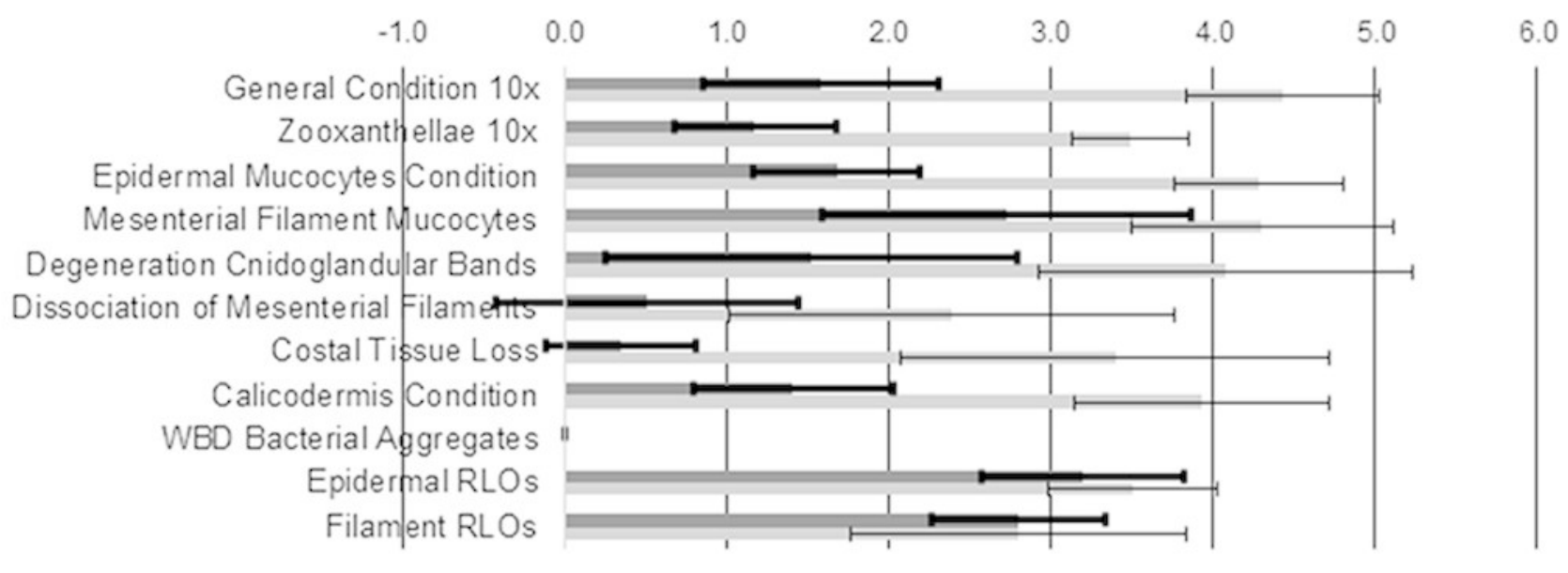

apparently Healthy $\quad$ Tissue Loss Disease

\section{B Tissue Condition, Mitigation Treatments}

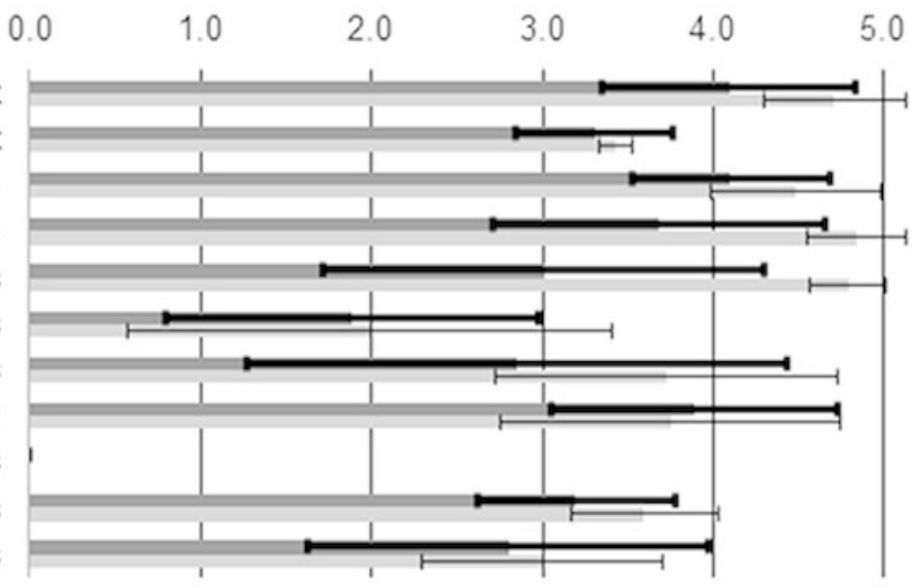

General Condition 10x

Zooxanthellae 10x

Epidermal Mucocytes Condition

Mesenterial Filament Mucocytes

Degeneration Cnidoglandular Bands

Dissociation of Mesenterial Filaments

Costal Tissue Loss

Calicodermis Condition

WBD Bacterial Aggregates

Epidermal RLOs

Filament RLOs

m Mitigation Successful $\quad$ Mitigation Not Successful

\section{Characteristics of WBD vs. RTL}

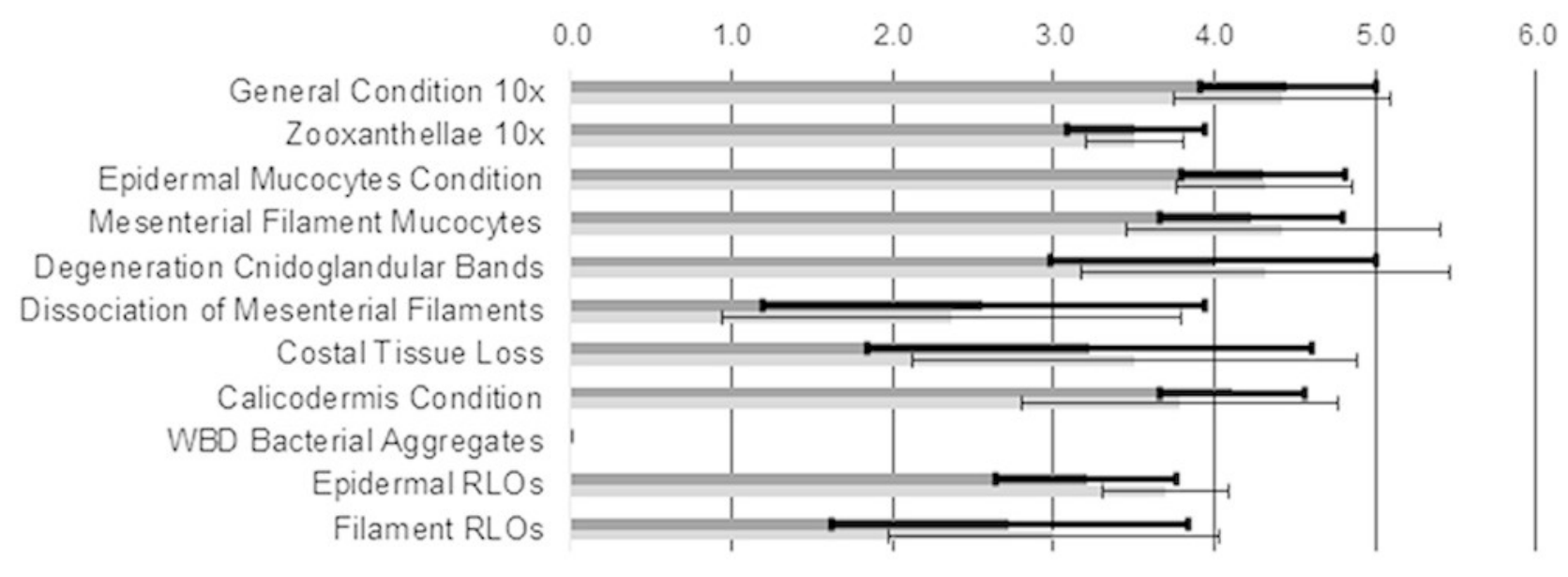

$\boxplus$ Characteristics of WBD $\equiv$ Characteristics of RTL 